\title{
Article \\ A Kurdish al-Qaida? Making Sense of the Ansar al-Islam Movement in Iraqi Kurdistan in the Early 2000s
}

Brynjar Lia

check for updates

Citation: Lia, Brynjar. 2022. A Kurdish al-Qaida? Making Sense of the Ansar al-Islam Movement in Iraqi Kurdistan in the Early 2000s. Religions 13: 203. https://doi.org/ $10.3390 /$ rel13030203

Academic Editor: Aje Carlbom

Received: 21 December 2021

Accepted: 15 February 2022

Published: 26 February 2022

Publisher's Note: MDPI stays neutral with regard to jurisdictional claims in published maps and institutional affiliations.

Copyright: (C) 2022 by the author. Licensee MDPI, Basel, Switzerland. This article is an open access article distributed under the terms and conditions of the Creative Commons Attribution (CC BY) license (https:// creativecommons.org/licenses/by/ $4.0 /)$.
Department of Cultural Studies and Oriental Languages, University of Oslo, 0315 Oslo, Norway; brynjar.lia@ikos.uio.no

\begin{abstract}
Initially construed as the vital link between Saddam Husayn's Iraq and al-Qaida in the runup to the Iraq war, the Ansar al-Islam (AI) group formed in Iraqi Kurdistan in December 2001 has been the subject of intense debate and huge media coverage. In academic research, however, its history, evolution and affiliation have received surprisingly little academic scrutiny. Commonly depicted as an al-Qaida affiliated group or a sub-group controlled by al-Qaida's emerging organization in Iraq (AQI), the AI group should — this article argues—instead be understood as a strong independentminded group with an ideology and operational pattern distinct from that of AQI. Although sharing many commonalities, the AI and AQI became de facto rivals, not allies. Contrary to accepted wisdom, the AI and its first successor group remained a distinct Salafi-jihadi insurgent group largely focused on fighting 'the near enemy', i.e., Kurdish and Iraqi authorities. It strongly resisted repeated calls for joining al-Qaida's new umbrella organization in Iraq, the Islamic State of Iraq (ISI) in 2006, and it paid no homage to AQI's or ISI's leaders. Also on the international level, the groups were fundamentally different. As opposed to al-Qaida's terrorist plotting abroad, the AI's international network were hierarchical structures, geared towards raising logistical and financial support as well as recruitment. The article highlights the need for greater attention to the complexities and nuances in patterns of contacts and cooperation between militant Islamist extremists. Informed by the growing scholarship on the multifaceted nature of contemporary jihadism, its numerous manifestations in local settings, and its strong internal rifts, this paper seeks to redress the early reductionist portrayal of the AI movement.
\end{abstract}

Keywords: Ansar al-Islam; al-Qaida; jihadism; jihad; Islamism; Iraq; Kurdistan; violence; insurgency; rebel movements; terrorism

\section{Introduction}

The nature and the role of the militant Islamist armed movement Ansar al-Islam (AI), officially formed in Iraqi Kurdistan in early December 2001, and its various offshoots, precursor and successor groups, has remained one of the more obscure subjects in academic scholarship and the public debate on al-Qaida and the jihadi movements. When the AI-group first caught the attention of international media, it controlled a dozen villages and towns in northern Iraq close to the Iraqi-Iranian border, having inherited the enclave from its predecessor groups. Media reports suggested that AI played host to al-Qaida fighters fleeing the US-led invasion of Afghanistan and received foreign jihadist fighters, arriving in preparation of a resistance campaign to the looming U.S. invasion. The media hype surrounding the group gained additional momentum after the U.S. government claimed that AI was a critical link in an alleged alliance between al-Qaida and Saddam Husayn's regime in Baghdad, and that the group ran a crude chemical and biological weapons program on its territory (e.g., Schanzer 2003; Hayes 2004; Hayes and Joscelyn 2005; Rumsfeld 2011).

While AI has been extensively portrayed in the media, relatively little scholarly attention has been devoted to understanding the group within the broader jihadi movement. 
Most studies fall within the category of 'grey' literature, including numerous reports published by think tanks and research institutions for policy analysis and threat assessment purposes or by NGOs raising human rights concerns (e.g., International Crisis Group 2003; Human Rights Watch 2003; Darling and Gunaratna 2004; Schanzer 2004a; Schanzer 2004b, pp. 127-54; Abedin 2004; Rubin 2004; Khalil 2005; Romano 2007). The group figures as an important topic in the well-reputed series of jihadism studies by The Combating Terrorism Center at West Point (see e.g., Fishman 2009; Lahoud et al. 2012). More recently, the movement's interaction with the Islamic State has been profiled by noted jihadism tracker and blogger Aymenn Jawad Al-Tamimi (Al-Tamimi 2015, 2017, 2020), and has also been explored as part of general studies of Islamism, Salafism and Jihadism in Iraqi Kurdistan (especially Tønnessen 2014; Bakawan 2017; Shareef 2015; Jalal and Ahram 2021).

While our understanding of the AI movement has matured since the early 2000s, much of the legacy of the reporting from the immediate pre- and post-invasion Iraq period still characterizes academic accounts where AI is mentioned. Widely portrayed as 'al-Qaida's Kurdish ally', 'Al-Qaeda's army', or 'al-Qaeda union' (O'Leary 2006, p. 297; Schanzer 2004a, p. 127; Celso 2014, p. 111), scholars have made much out of AI's alleged links to Abu Mus'ab al-Zarqawi (an alias), ${ }^{1}$ who was al-Qaida in Iraq (AQI)'s first commander, and the foremost icon in international jihadism until his death in a U.S. air strike in June 2006. In a well-known academic bestseller, 'Zarqawi: The New Face of al-Qaeda', AI was described as a group by-and-large controlled by al-Zarqawi (Brisard and Martinez 2005, p. 120). Others have portrayed AI as simply 'the forerunner of Al Qaeda in Iraq', founded by al-Zarqawi (Katzman 2008, p. 5). A more recent study argues that AI represented a shift from 'national jihad, to Osama bin Laden's paradigm of international jihadi' and that in this sense, AI 'officially merged with and became the Kurdistan branch of al-Qaeda' (Bakawan 2017, pp. 14-15). When the AI movement changed its name to 'Jaysh Ansar al-Sunnah' (JAS) in late 2003, this successor group was also portrayed as a Zarqawi-linked creature. $^{2}$ This was not simply an academic issue: the alleged links to al-Zarqawi and by extension, al-Qaida, were important in determining AI and JAS' status as banned terrorist organizations. ${ }^{3}$ Although the allegations of the AI's, and by extension al-Qaida's, ties with the Ba'thist regime have been roundly discredited along with the missing WMD, the claim that the group was basically an al-Qaida subsection has persisted and rarely receives the scrutiny it deserves, especially when the evidence cited is circumstantial.

This article argues that it is misleading to portray AI as simply an appendix to al-Qaida and al-Zarqawi's organisation. ${ }^{4}$ The $\mathrm{AI}$ is the oldest jihadist organisation in Iraq, is still in existence in the country (and in Syria after 2011) and its historical identity was formed separately from that of al-Zarqawi's organisation. Unlike the latter, the AI and its precursors had a history of running a jihadist proto-state in Iraqi Kurdistan over a number of years from the early and mid-1990s until 2003. It also had a well-established ideological focus and military strategy formed by years of confronting its 'near enemy' ${ }^{5}$ the secular left-leaning Kurdish faction of Patriotic Union of Kurdistan (PUK) which has administered the eastern part of the Kurdish self-rule administration in northern Iraq since the early 1990s.

Informed by the growing scholarship on the multifaceted nature of contemporary jihadism, its numerous manifestations in local settings, and its strong internal rifts as well as factors influencing the dynamics of alliance formations (e.g., Bacon 2018; Hafez 2020; Hamming 2019; Lia 2016), this paper seeks to redress the early reductionist portrayal of the AI movement. It argues that a more in-depth exploration of the movement also helps us make sense of its activities and activist networks outside of Iraq, especially in Europe. As opposed to the AQI movement, which was led by foreigners, and strongly influenced by ideologues, who viewed Iraq as the best arena to combat the Zionist-Crusader alliances for the time being, the AI movement appears to have been genuinely preoccupied with reclaiming its right to a territory, and a state entity, in Iraq. For this purpose, it pursued a long-term guerrilla war, including spectacular terrorist operations, and an extensive media campaign, but unlike many other Iraqi insurgent groups, it consistently eschewed any form of political participation. For AI/JAS, its various diasporic networks were invaluable 
sources of external funding, recruitment and media/propaganda outreach. Hence, the movement was disinclined to jeopardize this support by spearheading a campaign of international terrorism in neighbouring countries or in Europe. Although it shared much of al-Qaida's Salafist-jihadist ideology, in practice, the AI did not prioritize a global jihad. Furthermore, it strongly defended its independence in the face of strong pressure to merge with the AQI in the mid-2000s, while seeking to maintain 'brotherly relations' with many other jihadist outfits and ideologues. As opposed to a number of local jihadist groups in the Middle East who actively sought recognition as local branches of al-Qaida during the 2000s, with mixed success only, ${ }^{6}$ the AI did the opposite. It fiercely rejected AQI's marriage overtures, preferring instead to remain independent.

Beyond its empirical contribution, this article also speaks to the debate on entrenched counter-terrorism narratives and discourses in the post-9/11 era where individuals or groups with proven 'links' or 'contacts' with al-Qaida were equated with someone who shared bin Laden and al-Zawahiri's deadly intentions in their entirety. This rhetoric allowed little room for, or acceptance of, the idea that persons or entities may have contacts and even cooperate with al-Qaida members, and still disagree fundamentally with the latter's aims and tactics.

In the immediate post-9/11 era, the perception that groups and individuals who can be linked to al-Qaida are also al-Qaida was being reinforced by the various listing practices, whereby the US, the EU and the UN regularly updated their respective lists of banned terrorist entities, many of whom were described as linked to, or associated with, al-Qaida. While the conceptualisation of al-Qaida as a system of networks is in many ways fruitful (e.g., Mishal and Rosenthal 2005; Kahler 2010), it also makes us less perceptive of the idea that al-Qaida, defined as bin Laden's organisation in Afghanistan, and, after 9/11, its growing number of formal regional branches from Maghreb to South Asia, existed within a much larger and more heterogeneous landscape of salafi-jihadi movements, many of whom disagreed strongly with bin Laden on core issues. As recent research has shown, even among the official AQ regional branches, disagreements and controversies frequently arouse over a range of issues, including the prioritization of localnationalist ambitions, instead of AQ's stated objective of targeting US and Western targets first (see e.g., Byman 2014). The AI and its successor the JAS are only examples of a number of local jihadist groups that in the early 2000s came to be conceptualized and 'constructed' (e.g., Jackson 2007) through the prism of the post 9/11 terrorism paradigm of establishing linkages to al-Qaida.

\section{What Are the AI and JAS? Background and Ideological Orientation}

The AI group emerged out of a broad landscape of competing Islamist groups, most of them with roots in the Islamic Movement (IMIK) founded in 1987. As Iraqi Kurdistan became autonomous in 1991 following Iraq's withdrawal from the territories under U.S. and British pressure, IMIK emerged as the dominating Islamist party in the region. In the overall game of Iraqi Kurdish politics, however, it only played second fiddle to the two main secular-nationalist parties, the Kurdish Democratic Party (KDP) and Patriotic Union of Kurdistan (PUK). During the 1990s, a Kurdish civil war erupted from time to time between these factions, with the IMIK mostly facing the PUK. After a peace accord mediated by Iran in 1997, several smaller jihadi outfits made themselves known by defying the Accords and continuing skirmishes with the PUK (Romano 2007; Kakei 2013; Vindheim 2005).

The foundation of Ansar al-Islam in December 2001 was the result of a series of mergers between small Salafi-jihadi groups. The last merger included Islah ('Reform'), a faction headed by Mulla Krekar, formerly IMIK's top military commander and a skilled orator with a higher university degree in hadith studies from Pakistan, and the Jund al-Islam ('Soldiers of Islam'). The latter was itself the result of a previous merger, and represented the most militant and violent trends in Kurdish Islamism. It had a number of former Afghan war veterans in its ranks, both Kurds and Arabs (Oberlandesgericht München 2006, pp. 18-28; International Crisis Group 2003). The group was behind the Kheli Hama 
killings in late September 2001, one of the worst atrocities in the Islamist-PUK decade long confrontation.

The establishment of AI in December 2001 was partly a response to the need for a less confrontational leadership of the jihadi militants in the Halabjah area. With the creation of AI, the leader of Jund al-Islam, Abu Abdallah al-Shafi' $\mathrm{i}$, was relegated to the position of second in command, while Najmuddin Faraj Ahmad, better known as Mullah Krekar or Abu Sayyd Qutb Fatih Karikar, from the more moderate al-Islah faction, became the new 'emir' (ibid.). Krekar clearly wanted to distance the new organization from the violent excesses associated with the previous Jund al-Islam, and stressed in media interviews and in his autobiography that AI was a quite different organisation, not simply a continuation of Jund al-Islam with some cosmetic changes (Krekar 2004, pp. 108-17). The new leader did not expel or punish the perpetrators of the Kheli Hama massacre, however. In fact, his rhetoric in his numerous audiotaped speeches and sermons at the time could be bold and uncompromising, including claims that he himself also fought in the trenches with Jund al-Islam during 2001 confrontations with the PUK. And yet, Krekar's emirate was clearly geared towards some sort of peacemaking, justified as a temporary truce. In its early phases, AI would stress politics over the deployment of military force, as opposed to its militant predecessor, which had portrayed itself as primarily a military entity. Under Krekar's shortlived leadership, ${ }^{7}$ the group quickly embarked on a series of ceasefire negotiations with the PUK, which at least, for the time being, restored a semblance of normality to the area. The ceasefire talks had been a precondition for the December 2001 unification which installed Krekar as emir, even if it represented a departure from Jund al-Islam's policy of refusing any dealings with the PUK (Sorany 2012, p. 238). This new balancing act was difficult, however, and even under Krekar's 'moderate leadership', a high-profile assassination attempt occurred in April 2002, targeting Barham Salih, the PUK Prime Minister in Suleimaniya, a pro-Western politician who had served nearly ten years in Washington as his party's representative (BBC 2002a; Awena 2006; McKiernan 2002). ${ }^{8}$ After Krekar's departure from Kurdistan in May 2002, intermittent armed skirmishes and attacks resumed.

The difference between al-Qaida and Zarqawi's organizations on the one hand and the AI-JAS on the other hand become clear when the latter's ideology is scrutinized. True, the AI was clearly closer to the global salafi-jihadi movement than the traditional Islamist organisation, emanating from the Egyptian Muslim Brotherhood. Still, they differed from the global jihadis on one crucial issue, namely the imperative of fighting the near enemy first and carving out an Islamic state, based on the orthodox Salafist principles, in preparation for the coming battles against more distant enemies. Hence, even if the group professed an internationalist orientation, the time sequence was different. This can be seen from the way the group presented itself on its websites. The AI declared an ambition to support fellow Muslims in other parts of the world, both in terms of armed struggle and the call to Islam ( $\left(a^{\prime} w a h\right)$. It dedicated itself to establishing 'the rule of God and his law and assisting the Muslims everywhere in the way of struggle (jihad) and preaching $\left(d a^{\prime} w a\right)^{\prime}$ (Ansar al-Islam Website 2003a). The AI specifically pointed out that the reference to Kurdistan 'does not imply that its aims are regional or national' (ibid.). Indeed, AI referred to Kurdistan as a good starting point for a wider Islamic struggle. AI posed the rhetorical question 'Why in Kurdistan?' and presented the following answer:

The intention behind this limitation is to begin from the Muslim land of Kurdistan because of the presence of suitable conditions for the spread of the Islamic revival among the Muslim people of Kurdistan, and because of the rugged geographic nature of the mountainous region and its vastness. (ibid.)

The AI was clearly more preoccupied with consolidating its small Islamist rebel state in Northern Kurdistan than training and preparing its fighters for operations overseas. Hence, the war on its near enemies, who stood in the way of the formation of a true Islamic state in Kurdistan, assumed highest priority, not the global jihad of al-Qaida. True, the AI rhetoric contained many elements of global jihadism ideology. At the same time, 
however, it also revealed a distinct underlying Kurdish identity, and a certain Kurdish nationalist sub-current manifested itself in different ways. For example, the AI made much out of the historical importance of Kurdistan, being the birthplace of 'the great Islamic commander Salah al-Din al-Ayubi, who defeated the Crusaders and conquered Jerusalem' (ibid.). It issued many communiqués in Kurdish, and its websites were primarily in Kurdish, although significant sections were translated into Arabic, and some items also appeared in Turkish, Farsi and English versions. Even though AI also had both Iraqi and non-Iraqi Arab members, the leadership remained overwhelmingly Kurdish, even after AI (and its successor group) expanded its operations beyond the Kurdish region to the Iraqi provinces further south. ${ }^{9}$

In his memoirs the AI's first leader, Krekar recalled how difficult it had been to raise funds for the Kurdish Islamist movement among Arab donors from the Gulf in the 1980s, because the latter mistrusted the Kurds because of their rebellion against an Arab state. Hence, the Kurdish diaspora in the West became their primary support base in exile (Krekar 2004, p. 78). Much later, in an interview with a jihadi media outlet in May/June 2010, Mullah Krekar similarly complained about the Arab mujahideen leaders in the Sunni triangle who had received generous assistance from Kurdish rebels, but who failed to return this favour (Ansar Media Center's Website 2010, audiofile: 26:30-27:25). ${ }^{10}$

Contrary to most of its Salafi-jihadi sister organisations around the world at the time, the AI had a high degree of territorial control in its enclave Iraqi Kurdistan, primarily in Biyara, Tawila and a number of other towns and villages near the Iranian border in the Suleimaniya governorate. Thus, the group had to deal with the substantial and mundane issues of governance, in addition to the exigencies of the continued struggle for survival in the face of its secular Kurdish adversaries who sought to curtail and preferably eliminate the AI as a territorial entity. This reality forced a local and Kurdish orientation upon the AI, even if the movement in principle had dedicated itself to prepare for a pan-Islamic jihadi struggle. The needs to preserve its bases and provide for their families and fighters figured prominently in their numerous appeals for assistance and help from their foreign sympathisers. This is evident from numerous postings on AI's websites in the period between 2001 and 2003 (Ansar al-Islam Website, 2003h).

As with many other jihadi organisations, the Ansar al-Islam was eager to prove its Islamic credentials and the soundness of its ideological program. Hence, it established a juridical committee to issue authoritative juridical rulings, formed Islamic courts, maintained contacts with leading Salafist scholars in other Islamic countries, particularly in Saudi Arabia, and formulated a doctrinal document, entitled 'Our Doctrine and Program' ('Aqidatuna wa manhajuna), which was subsequently posted on AI's websites (Ansar al-Islam Website 2003g). The latter provides some insight into its ideological orientation and reveals several points of divergence with other salafi-jihadi groups that emerged in Iraq after the US-led occupation commenced in March 2003.

The document leaves little doubt about its strictly Salafist-jihadi orientation, especially with regard to the fierce Salafist opposition to liberal interpretative trends in Islam. ${ }^{11}$ The jihadi dimension is also prominent in AI's 'Our Doctrine and Program', but the focus on jihad as an individual duty of every Muslim (farida 'ayniyya) is not so dominating, as it often is in much of the contemporary Salafi-jihadi literature. In contrast to jihadi groups, which emerged in post-Saddam Iraq, including its successor, the JAS, and the AQI, there is no endless repetition of the obligation to wage jihad. Instead, the AI stresses the need to 'complete the preparation for jihad before it can begin' and that followers should 'heed the advice of the active clerics and learn from the experienced mujahidin in the world. We will accept their advice and guidance' (Ansar al-Islam Website 2003g). Clearly, at the time of writing 'Our Doctrine and Program' (probably in late 2001 or 2002) the AI considered itself in the preparatory phases of jihad and the time for full-scale war had not yet come. The emphasis on learning more from 'the experienced mujahidin in the world' (ibid.) might, of course, be interpreted as a hint about the much-touted relationship with al-Qaida-linked veteran fighters arriving from Afghanistan in small numbers in 2002. A 
more likely interpretation, however, is that this was a stated commitment to a leadership guided by, if not Islamic scholars (ulama'), so at least 'Islamic intellectuals', leaders with some Islamic learning, as had been the tradition in Kurdish militant Islamism since the foundation of the Islamic movement of Kurdistan in 1987 (Al-Tamimi 2015; Bakawan 2017).

The AI's conflict-ridden relationship with the dominant Kurdish faction in the region, the Patriotic Union of Kurdistan (PUK), strongly influenced the AI's discourse on jihad. Consequently, the AI was less preoccupied with the 'far enemy', the Crusaders (the United States, Israel and their allies), and was more focused on the threat from its near enemies, the 'secular', 'communist', 'apostate', 'Jewish' PUK and its leader Jalal Talebani. This obsession with fighting 'the local traitors' did not change dramatically in the wake of the US-led occupation of Iraq and the bombings of AI's bases in March 2003. For this reason, the AI adopted, at least in practical terms, a 'takfiri' approach in terms of legitimating armed attacks on fellow Muslims, even if it claimed in its doctrinal document that it shunned the khawarijitte position and an excessive use of takfir (i.e., the 'excommunication of Muslims') (Ansar al-Islam Website 2003g).

Hence, in terms of legitimating brutal means of warfare, the AI/JAS must be considered as lying at the extreme end of the scale. AI's immediate precursor, Jund al-Islam, was implicated in decapitations of POWs in late 2001 (Human Rights Watch 2003), and the JAS gradually became one of the most proliferate users of the beheading tactics among all the Iraqi insurgent groups. Still, it shunned away from mass killings of Shiite civilians, a method attributed primarily to al-Zarqawi's group (Tawhid wa'l-Jihad and after 2004, the $\mathrm{AQI}$ ). Both AI and its successor group, JAS, went far in legitimising 'terrorism' (irhab) and finding theological justifications for such tactics. For example, in one of its public communiqués in early 2003, the AI's Shura Council, commenting upon an assassination carried out by its fighters, wrote that 'terrorising the infidel parties (irhab fi'at al-kufr) and killing them is a duty' (Ansar al-Islam Website 2003c). ${ }^{12}$ Similarly, the JAS online periodical spoke in an editorial in mid-2004 about the 'praiseworthy terrorism' (al-irhab al-mahmud) in Islam, and about the inescapable obligation of the believers to be 'the people of praiseworthy terrorism who rock the bed of the infidels' (Majallat Ansar al-Sunnah 2004). Interestingly, the AI's use of assassinations and other terrorist tactics seems to have given rise to serious misgivings within $\mathrm{AI}^{\prime}$ s ranks, and the AI's Shura Council admitted that:

it is possible that the issue of doubt will come up here and there within the [AI's] ranks, and that someone will say that the Ansar has betrayed 'the safety' (aman) to those that were promised 'safety'. Beware not to fall into this trap. This is another mistake in the understanding of 'safety', its preconditions, and the things that result from it. (...) This doubt which we hear from here and there has no legal basis and we may say it is caused by ignorance of Islam and the Prophetic Traditions. (Ansar al-Islam Website 2003c)

The AI was adamant that its tactics were justified and within the boundaries of legitimate actions of jihad and represented 'a renewal of the Prophet's tradition of killing and suppressing the imams of unbelief' (ibid.). Besides this, the AI's enemies, the PUK, had conspired to split and suppress the jihadists, and the AI's actions could be construed as selfdefence. It therefore announced proudly 'without any concealing' the AI's responsibility for such operations, including the ambush in February 2003 in Qamesh Tapa, near Halabja where three PUK government officials, amongst them Shawkat Hajji Mushir, a PUK minister, were killed. The latter had agreed to meet with members of an AI group who ostensibly had been receptive to the idea of defecting from the AI (New York Times 2003a). Hence, there was some truth in the AI's allegations that the PUK 'conspired' to split the movement. Mullah Krekar stated in an interview with the London-based al-Hayat newspaper, which was subsequently posted on Ansar al-Islam's website, that the assassination of the PUK officials was a fully justified 'security operation in response to PUK's attempts to split the AI' (Ansar al-Islam Website 2003f).

The attack aroused much resentment against the AI in Iraqi Kurdistan. Previously, the AI had also attacked PUK bases during the Feast of Sacrifice celebrations at the end of 
the holy month of Ramadan, even though this was a flagrant violation of the tradition of ceasefire during the Feast of Sacrifice. The AI nevertheless fully defended the decision to exploit religious celebrations to gain a military advantage. According to a Shura Council communiqué, the AI's 'wise leadership and brave decision-makers (...) fully believe in "war of deception"' (Ansar al-Islam Website 2003c).

Hence, it seems clear that AI despite some early efforts at peacemaking, established itself as a hardline movement embracing extreme methods of warfare. Being a product of a violent context in which nearly all political parties also kept their own militias, the AI nevertheless distinguished itself by going beyond accepted norms of warfare in the area. This tendency to resort to unconventionally brutal methods to terrorise and punish its enemies, especially those whom it considered traitors and apostates, also became a hallmark of the AI's successor, the JAS. Still, its use of salafi-jihadi ideological discourse and brutal methods of warfare should not mislead us to assume that the AI was about to become a local chapter of al-Qaida.

\section{The Iraq War and the AI's Transformation}

The U.S.-led invasion of Iraq in March 2003 dramatically changed the geopolitical landscape for the AI. Not only did it become more radical and uncompromising in ideological terms, but the war also prompted the group to introduce new tactics of warfare and it greatly elevated the U.S. and its coalition partners in the group's ideological hierarchy of enemies. More importantly, however, the war encouraged the AI to expand its arena of operations to the sunni-Arab region to which several of AI's most experienced Kurdish cadres gradually relocated (e.g., Ansar Media Center's Website 2010, audiofile: 26:30-27:25).

\subsection{Al-Zarqawi and Foreign Fighters in Iraqi Kurdistan}

The US-led military build-up in the region in preparation for the invasion made the $\mathrm{AI}^{\prime}$ s territorial enclave in northern Iraq an attractive destination for Arab volunteer fighters who previously had fought in Bosnia, Chechnya or Afghanistan. The AI's contingency of non-Iraqi Arab mujahidin, including AQIs future commander, Abu Mus‘ab al-Zarqawi, has often been cited as evidence for AI's close relationship with the al-Qaida in Afghanistan. The actual presence of foreign fighters is still shrouded in uncertainty. Little openly accessible information has been available to substantiate what was already in December 2002 referred to as 'this oft-repeated assertion' (New York Times 2002b). Nevertheless, both media and the academic literature have frequently posited the presence of Afghan war veterans and foreign Arab mujahidin in AI's territory as a fact, (see e.g., Goldberg 2002; Darling and Gunaratna 2004; International Crisis Group 2003; Human Rights Watch 2003; Schanzer 2004b). Although most estimates range around 200 or fewer, recent studies nevertheless speak of a 'massive influx of al-Qaeda jihadists' already in 'early 2002' (Bakawan 2017, p. 15). Most accounts lean heavily on Zarqawi: The Second Generation of al-Qaeda, a book by the Jordanian journalist Fu'ad Husayn, which contained a biography of al-Zarqawi penned by a senior al-Qaida member (Al-Adl 2005; Husayn 2005). However, as Fishman (2016) has shown, this source needs to be treated with caution.

There is little doubt that there was a small, but increasing contingency of foreign Arab fighters in the AI enclave in 2002 and 2003. This author systematically collected jihadi media sources during the early and mid-2000s about AI and its foreign fighters in Iraqi Kurdistan. These sources include postings on the various AI websites and on jihadi web forums prior to and after the Iraq invasion, including a number of Arabic language biographies (or rather hagiographies and eulogies), detailing the life, heroism, and martyrdom of Arab mujahidin who fought and were killed in Iraqi Kurdistan in 2002-2003. By the end of 2002, the AI had established a special unit for foreign fighters, sometimes termed 'The battalion of foreigners' (katibat al-ghuraba') (Ansar al-Islam Website 2003i).

With the influx of foreign fighters, the AI enclave came into the CIA spotlight as 'hub for al-Qaida operations' (e.g., Tenet 2007, p. 531; Goldberg 2003). ${ }^{13}$ One of the most prominent Afghan veteran arrivals in northern Iraq was Abu Mus'ab al-Zarqawi, who 
already by then had gained international notoriety after masterminding the assassination of a U.S. Aid official in Amman in October 2002 (New York Times 2002a). Al-Zarqawi had little interest in the outcome of the skirmishes between Islamist and secular Kurdish factions in northern Iraq. Instead, as related by his biographer, al-Zarqawi had told his followers he 'believed Iraq would be the forthcoming battlefield against the Americans' (Husayn 2005). His group also had contacts with 'some brothers' further south in the Anbar province and established a camp in that region, awaiting the outbreak of the war and the downfall of the Ba'thist regime (Al-Adl 2005).

Overall, there is limited information available about the foreign fighters' relationship with the AI in northern Iraq during this period. While their number was small in the beginning, the Arab fighters formed their own training camps and facilities, one in Dargha Khan on the Iranian border and another in Bakhun, with training including military, religious and spiritual training. They were organized separately in a 'battalion of Arab mujahidin', with their own commander, and when travelling between the camps, AI leaders often accompanied them (Tønnessen 2014, p. 152). During a military operation against PUK targets in late 2002 one of the leading Jordanian foreign fighters was tasked with commanding one of the assaulting AI units, suggesting close military cooperation.

Such cooperation does not necessarily imply a warm embrace of global jihadism and an application for the position of the Kurdish al-Qaida. Indeed, for AI's Kurdish members the lesson from Afghanistan must have been clear. The Taliban regime had just been ousted due to its overt hospitality to al-Qaida. Hence, in the interest of selfpreservation, the AI had a strong interest in minimizing the visibility of foreign fighters on its territory, especially those arriving from Afghanistan. Until the outbreak of the Iraq war, the AI leadership never acknowledged the presence of non-Iraqi mujahidin on its territory. Instead, during Mullah Krekar's shortlived reign as AI's emir, the severance of all external links to non-Iraqi mujahidin was, at least publicly, a stated policy objective for the group (Krekar 2004, p. 112). It is possible that Krekar's permanent residency in Oslo since the early 1990s led him to minimize and obscure AI's connections to Afghanistan. However, even after Krekar's arrest in Tehran and deportation to the Netherlands in September 2002, when Krekar's deputy Abu Abdallah al-Shafi'i, had taken over as AI's top emir, first temporarily, then permanently (from February 2003), AI spokesmen continued to officially maintain the group's independence, which meant having 'no outside affiliations' (New York Times 2003a).

A key building ingredient in the 'AI is affiliated with al-Qaida'-argument was that it hosted Afghan war veterans and non-Kurdish foreign fighters, some of whom reportedly arrived from Afghanistan. This is problematic on several accounts. While there undoubtedly were a number of both Kurdish and Arab fighters in the AI enclave who had fought in Afghanistan, their relationship to al-Qaida and bin Laden was not necessarily very close, for several reasons. Many jihadis in Afghanistan had frankly disagreed with bin Laden on ideological and tactical issues. Among them was al-Zarqawi, who did not pledge allegiance to bin Laden due to ideological differences (e.g., Fishman 2016; Husayn 2005). Another bin Laden critic was Abu Mus'ab al-Suri, ${ }^{14}$ whose opposition to bin Laden was well-known inside as well as outside jihadi circles (Lia 2008; Farrall and Hamid 2015). Furthermore, Taliban-ruled Afghanistan hosted more than a dozen separate non-Afghan militant Islamist factions with their own guesthouses and training camps, many of which did not consider themselves allied with, or subservient to, al-Qaida (Lia 2008, pp. 246-50). Al-Zarqawi (and perhaps also al-Suri) spent time in the AI enclave after the downfall of the Taliban regime (Lia 2008, pp. 329-30). Al-Zarqawi had formed contacts with Kurdish militants back in Afghanistan and Iran, and the latter promised to help a fellow jihadi on the run. Another foreign fighter arriving in the AI's enclave was a Saudi-born jihadi veteran, called Yasin al-Bahr. ${ }^{15}$ He already enjoyed a position of prominence and seniority in jihadist circles after having fought as a foreign fighter in Bosnia, Chechnya and Tadjikistan, but he was similarly not close with the al-Qaida leadership. He had spent the latter part of the 1990s in a Saudi jail. Upon his release, he travelled to Iraqi Kurdistan. His story was not 
unique. It appears that a number of foreign fighters entering AI's territorial enclave did not come directly from Afghanistan via Iranian territory, but arrived from Saudi Arabia or from Jordan where a number of Salafi-jihadi prisoners had been released. In fact, according to Truls Tønnessen's research, there was already a small contingency of Jordanians in AI's area before al-Zarqawi's arrival. Some of them died in battle before al-Zarqawi turned up in spring 2002 and a few ended up with other rebel groups than al-Zarqawi's (Tønnessen 2014, pp. 145-50). A number of Sunni Arabs associated with outlawed Islamist movements chafing under Saddam's harsh rule, also sought refuge in AI's enclave prior to the Iraq war (ibid.). They too lacked organizational links to bin Laden in Afghanistan.

Judging by their names and profiles, Saudi Arabia appeared to have the largest share of the foreign fighter contingency in Iraqi Kurdistan (Ansar al-Islam Website 2003e), a common pattern in many jihadi fronts since the mid-1980s (Hegghammer 2011). Lists of martyrs in the Arab Brigade in Iraqi Kurdistan in 2003 circulating on jihadi media outlets at the time suggest that the number of foreign fighters was relatively low. The longest list of martyrs contains 18 names only. Judging by their names and available biographical information, of these 18 men, there were ten Saudis, four Algerians, one Iraqi Arab, one Syrian, and two whose nationality is unknown (Ansar al-Islam Website 2003e; Qisas Shuhada' al-'Arab 2003). CIA estimates of foreign fighters in Northern Iraq, however, put the number as high as 200 (Tenet 2007, p. 350).

There were several reasons why people such as Yasin al-Bahr went to join the Ansar al-Islam group in northern Iraq. After the collapse of the Taliban government, one of the primary destinations for jihadi globetrotters had disappeared. Secondly, the US military build-up in the region for a possible invasion of Iraq provided an important new focus for the internationalist jihadi community. The small enclave that the AI had carved out for itself in Northern Iraq suddenly emerged as an important 'Land of Jihad' that had to be defended at all costs. The heavy Western media focus on the AI, and 'in particular the US threats against them', further enhanced its importance in the eyes of the jihadists (Ansar al-Islam Website 2003i). It was easy for the jihadis to portray the small, beleaguered AI enclave as a miniature image of the Muslim Ummah. Moreover, as with a number of other Saudi jihadis who joined the AI in this period, Yasin al-Bahr saw the AI enclave as a true Islamic Emirate, and a dar al-hijrah, a legitimate place to which the Believers should make the 'emigration' (hijrah), a view that had been endorsed by several prominent Saudi clerics (ibid.).

\subsection{The Desctruction of the Kurdish Jihadist Emirate and AI's Radicalization}

In late March 2003, the U.S.-led forces in Iraq launched an all-out attack from land and air aided by thousands of Kurdish peshmerga fighters loyal to the PUK. The combined USPUK forces easily overran the AI enclave. The early bomb raids were aimed at eliminating rear threats to the U.S. and Kurdish military forces preparing for the imminent offensive towards Saddam Husayn's army further south (Finlayson 2005). In addition, the U.S. administration believed the early assault on AI's enclave might possibly eliminate alZarqawi and other 'al-Qaida-linked' terrorist hiding out there. The US Administration failed in its aim, but the attack undoubtedly radicalized the remaining AI fighters. In the pre-war period, the AI leadership had conducted peace talks with the PUK, and it had made some efforts at removing or at least reducing the visible presence of foreign fighters on its territory. Under Krekar's leadership, it had signaled a certain willingness to find at least a temporary modus vivendi with its enemies. However, the invasion of Iraq and the massive attack on the AI's bases consolidated the belief that the AI faced extinction and that it was being betrayed by everyone, even its closest Kurdish Islamist allies. The Komala Islamic Group, headed by Ali Bapir, with whom the AI had cooperated closely, refused to help or join forces with the AI, even though Komala facilities also had been hit by four U.S. cruise missiles (The Guardian 2003). Even though the AI's fighters expected an assault and had prepared defensive positions and trenches, their losses were significant. Some estimates put their number of killed militants as high as 250 of the 700 to 800 , including many of their 
foreign fighters (e.g., Apostolou 2004). A mass killing of this scale could not have left the movement untouched, and it clearly paved the way for a more uncompromising ideology in which ceasefires, peace talks and compromises had no place.

After fleeing across the border to Iran, the movement reorganized and quickly returned to assert itself as one of the most active and violent insurgent groups in the mid-2000s. The movement's relatively swift comeback following its crushing military defeat in March 2003, suggested at least some degree of Iranian facilitation, or at least tolerance, of AI activities on Iranian soil (e.g., Khalil 2007a; Romano 2007). There is little doubt that Iran took a keen interest in, and even courted, Kurdish Islamist groups in Iraq, seeing them as a useful counterweight to the two dominant nationalist Kurdish factions and as a vehicle for asserting influence. During the 1990s, Iran had repeatedly mediated in the conflict between the PUK and its Islamist adversaries. Later, it seemed to tacitly tolerate, with occasional interruptions, Ansar al-Islam militants operating on both sides of the border (Romano 2007; see also Khalil 2007a). ${ }^{16}$ It is debatable, however, whether Iran would have been able to eradicate completely AI activities in the border areas, if it had wanted to. Its control over the Kurdish areas in the northwestern Iran was rattled by periodic unrest as well as separatist violence, by Iraq-based Kurdish groups, which Iran claimed received covert support from the US (BBC 2007). The country also faced a proliferation of anti-Shiite Salafism in their Kurdish communities (Malazada and Nariman 2019). In other words, Iran had many reasons for keeping a close eye on AI activities, and it would crack down on Iraqi Kurdish militants when their overt presence in Iran proved an embarrassment. Hence, in September 2002, when AI's founder Mullah Krekar gave an interview to Al-Jazeera from Tehran, Iranian authorities promptly arrested Krekar and deported him to the Netherlands (Dagbladet 2002).

Although having had non-Kurdish members from the very beginning, the movement became 'more broad-based and less overtly-Kurdish' after the regrouping in 2003 (Parliament of Australia 2009, p. 38). The leadership remained mostly Kurdish, however, and it continued to have an operational presence in the Kurdish areas despite the fact that the security environment was more permissive in the Sunni Arab areas further south. On an operational level, the 2003 defeat also brought about changes. First and foremost it inaugurated the use of suicide operations, which so far had only been used sparingly by the AI. The influx of foreign volunteers was a critical factor in introducing and expanding the use of the martyrdom weapon. In fact, many of its early suicide operatives were reportedly non-Iraqi Arabs, not Kurds. (Accord 2006). The first successful AI suicide bomber was reportedly the 21-year-old Abu Hur. ${ }^{17}$ His real name was 'Abd al-'Aziz bin Su'ud bin Muhammad al-Gharbi from Dammar in the Saudi province of al-Sharqiyyah, and one of the late arrivals in Iraqi Kurdistan. He was assigned to a martyrdom operation against a crowded checkpoint near Khurmal where the PUK forces were stationed. On 21 March 2003, shortly after the first US air raid on AI's camps, Abu Hur drove a boobytrapped car up to the checkpoint, killing three PUK soldiers and an Australian journalist (Ansar al-Islam Website 2003j). Since the checkpoint was packed with refugees at the time, the number of civilian casualties could have been much higher. The AI's military committee lauded the attack 'a blessed jihadi effort rare in its kind', and described the attack as a new tactic, which dealt 'a painful and severe response to God's enemies for their aggression which they launched yesterday morning on our territories in co-operation with their masters, the Crusaders' (Ansar al-Islam Website 2003d; Muntadiyat al-Hikma 2005). Abu Hur's car bomb attack was celebrated as the AI's first martyrdom operation, which was soon followed by many more. A number of the surviving Saudi foreign fighters returned to the Kingdom after the AI's defeat and their stories about the 'Arab martyrs' in Iraqi Kurdistan were picked up and cited in Saudi newspapers (Ansar al-Islam Website 2003e). Hence, the desire to avenge their brothers was kept alive, and the mythology surrounding the mujahidin martyrs served to motivate new recruits to go to Iraq (Hegghammer 2007; Hafez 2007). 


\subsection{From Ansar al-Islam to Jaysh Ansar al-Sunnah}

The destruction of the AI's bases eliminated the state consolidation phase, and paved the way for the emergence of an underground jihadi organisation, whose single focus was the military struggle, hence the name the Ansar al-Sunnah Army (i.e., Jaysh Ansar al-Sunnah, JAS). The inclusion of the term 'sunnah' (i.e., the way of the Prophet) was probably meant to increase the organization's appeal among the Sunni-Arab population, and make explicit the new start outside the Kurdish areas of northern Iraq. Indeed, the Kurdish identity of the group seems to have declined after 2003, even though the group continued to release some of its publications in Kurdish, and maintained some of its website contents in Kurdish. Indicatively of the shift was an interview, given by a JAS spokesman to a Beirut-based journal, in which he heaped praise on the glorious history of the Iraqi army in a manner which most Kurds would have felt repugnant (Al-Muharrir Weekly 2004, pp. 24-25). The leadership of JAS remained mostly Kurdish, however, with AI's former deputy, Abu Abdallah al-Shafi'i, an Iraqi Kurd, assuming the role of emir.

AI's founder, Mullah Krekar, who promoted himself as Kurdistan's Sayyid Qutb and whose ideological horizon had always been pan-Islamist jihad, yes, but in Kurdistan, had by February 2003 been deposed by the AI's Shura Council for his media statements which 'violated Islamic doctrine' (Stavanger Aftenblad 2003). For the next 18 years, he would remain in Norway and from there he would launch a new mostly diaspora-based Kurdish organization, Rawti Shax, which remained mostly separate from the AI/JAS insurgency in Iraq. It grew gradually out of a network of Kurdish-language websites and virtual platforms, in particular PalTalk chat rooms, where seminars and educational sessions were held, with Krekar as the top instructor and preacher. Operating under a host of different names, the Rawti Shax network would have "a Salafi-Jihadi orientation", using AI "as its inspirational model", but during the late 2000s it remained focused on building its organizational and administrative structure (Västmanslands Tingsrätt 2012). German investigators suspected, however, that the Rawti Shax was the political front organisation of a small jihadist outfit, al-Qaida's Kurdistan Brigades (AQKB), active in Northern Iraq between 2007 and 2012 (ibid.). ${ }^{18}$ In 2006, Krekar had also been listed by the United States and subsequently the United Nations as "terrorist facilitator" partly because a Europeanbased NGO, founded by Krekar, had reportedly funneled money and recruited members to JAS (U.S. Department of the Treasury 2006). ${ }^{19}$

Although the JAS was officially created only in September 2003, according to its own publications it had been active since May 2003. JAS took a hardline position on most issues related to Iraqi politics. It blasted the Iraqi elections, all candidates, as well as anyone who cast their ballot in the election, as infidels, and vowed that 'its fighters would strike hard against the polling stations' (Jaysh Ansar al-Sunnah Website 2004a). The JAS repeatedly attacked polling stations and election officials. Surpassing most other Sunni insurgent group in perpetrating violence against Iraqis, the JAS was determined to punish collaboration with the enemy. To this end, it terrorized Iraqi civilians, seeking to deter them from assisting or working for the Iraqi government and Coalition forces as well as the Kurdish self-rule government. A particularly violent attack was a multiple suicide attack targeting the PUK's and KDP's headquarters in Erbil on 1 February 2004 at the start of the Muslim festival of Eid Al-Adha, in which at least 105 people were killed (Parliament of Australia 2009, p. 38; Maisel 2018, p. 73). The group also gained much media coverage for a suicide attack inside the US Forward Operating Base Marez in Mosul, the single deadliest attack on a U.S. military installation during the war in Iraq. Having infiltrated the base, the Saudi-born suicide bomber entered the restaurant area and detonated his device, killing 23 people, including 18 Americans, while the JAS's media department videotaped the explosion from a nearby house, and posted the video online (Task \& Purpose 2020).

By late 2005, the group had become, by some accounts, the most prolific perpetrator of executions and decapitations of prisoners and hostages among the Iraqi insurgent groups. ${ }^{20}$ In its review report regarding the relisting of JAS as a terrorist organization, the Australian government noted in 2009 that by 2004, 
[JAS]' tactical repertoire was already extensive and traversed the full range of insurgent operations for which the group is currently renowned, including suicide attacks, car bombings, emplaced improvised explosive devices (IEDs), hostagetaking, executions, assassinations and conventional military attacks. By February 2007, Ansar al-Sunna had claimed responsibility for approximately 1600 attacks in Iraq. (Parliament of Australia 2009, p. 38)

\subsection{From 'Army' to 'Society': The (Distant?) Ambition to Build an Islamic State}

The AI's mini-state in northern Iraq from 2001 to 2003 appears to have left a legacy of a state building ambition in the AI/JAS. With the increasing prospects of a U.S. military withdrawal from Iraq, the JAS decided to remodel the organisation to broaden its political appeal and prepare for the coming phase. In May 2006, the Shura Council of JAS announced that it would change its name from Jaysh Ansar al-Sunnah to 'Jama'at Ansar al-Sunnah' (i.e., from 'The Ansar al-Sunnah Army' to 'The Society of the Ansar al-Sunnah') (Al-Hesbah.org 2006). The background to this, the Shura Council explains, was that over the past three years following the invasion of Iraq, "we have managed [...] to develop "the army" into "a society" with an administration running the affairs of the mujahidin and to build the kernel which will bring the state of Islam back, with God's permission' (ibid.). Internal strength was key to the success of this process and the JAS Shura Council emphasized the importance of raising the ideological awareness of its fighters properly. Although 'many of the fighters have learnt how the jihadi work should be conducted and the cause had crystallized before their eyes, more [education] is still necessary,' the Council insisted (ibid.). This signaled a broader strategy of building a political-ideological platform for the coming phase of state consolidation in Iraq, apparently hoping to start with pockets of liberated areas in the sunni triangle. This was to be achieved without any engagement with the Iraqi political scene, however.

In the JAS's ideology, the imperative of forming a state on the basis of Salafist principles clearly took precedence over national liberation. From the very beginning, the JAS ideologues had stressed that the group's aim was not simply 'to expel and massacre the Occupier', but 'to establish the rule of God's religion on earth'; their struggle would be 'meaningless' if power was to be 'handed to a secular apostate Iraqi who served the Americans as a slave...' (al-Marsad al-I'lami al-Islami 2003). In other words, the character of the new regime was far more important than simply expelling the US Coalition. In the JAS' ideological texts, we find explicit condemnation of national liberation as the underlying goal of JAS' struggle. At the time of the battles for Faluja in late 2004, the JAS emphacized that 'Faluja is not dearer to us than Afghanistan or Chechnya or any other of the Muslims' land. God's enemies can be certain that our combat is not for a country or a region. It is to make God the Exalted and Supreme's law rule on earth' (Jaysh Ansar al-Sunnah Website 2004b).

\subsection{The JAS in the Iraqi Salafi-Jihadi Landscape}

The proclaimed commitment to a global jihad ideology, the state ambitions and its uncompromising position on political participation contributed to placing JAS very close to al-Zarqawi's organization in Iraq, Jama'at al-Tawhid wa'l-Jihad. The latter was officially formed in 2003 and renamed al-Qaida in the Land of the Two Rivers (or al-Qaida in Iraq, AQI) in October 2004 when it became al-Qaida's official branch in the country. There is little doubt that there was competition and rivalry between the two groups over hegemony and dominance over the salafi-jihadi scene in Iraq and support from the diaspora of jihadi sympathisers worldwide, a battle which AQI clearly won (Al-Tamimi 2015). This was not publicly evident from the very beginning, which explains why many analysts tended to group the two together under the same label.

The JAS ideologues emphasize ideological purity and display skepticism as regards being seen as working closely with other insurgent groups. The most explicit example of this is its unwillingness to join forces and merge with the al-Zarqawi-led organisation in Iraq since his arrival there in 2002, and his appointment as al-Qaida's official representative 
in Iraq in late 2004. A host of other insurgent groups operating in Iraq chose to fight under Zarqawi's banner, the umbrella organisation Mujahidin Shura Council (MSC) and later The Islamic State of Iraq (ISI) in which AQI was the dominating component. However, the AI/JAS distinguished itself by withstanding heavy pressure to do so. While a number of Iraqi insurgent groups began posting their statements, communiqués and videotaped operations as part of the MSC/ISI, the JAS continued to issue all its publications separately.

True, the JAS did congratulate 'our brothers in Jama'at al-Tawhid wal-Jihad' (i.e., al-Zarqawi's organisation) in 2004, at the time of the US elections, after the US announcement that the latter group had been listed as a banned terrorist organization (Jaysh Ansar al-Sunnah Website 2004c). The group's military committee has also released several communiqués in which the organization assumes responsibility for joint operations with other insurgent groups, including al-Zarqawi's organization as well as MSC. (e.g., Jaysh Ansar al-Sunnah Website 2004d, 2004e). However, interestingly, the JAS rarely reported on such joint operations themselves. Furthermore, when other Iraqi insurgent groups reported to have cooperated with JAS or received assistance from JAS, the JAS warned its readers not to heed such communiqués. (e.g., Jaysh Ansar al-Sunnah Website 2004f). This happened especially in cases where media sources had reported that JAS worked with elements of the ousted Iraqi regime. In October 2003, a group of local JAS commanders were interviewed by the Spanish daily El Mundo. The daily subsequently reported that the group included Iraqi army ex-soldiers and former Saddam-militia fighters, apolitical Sunnis, as well as both Shi'ites (!) and Salafi fighters. The persons interviewed emphasized their common aim, 'shared by all insurgent groups'. (Prieto 2003). This interview immediately prompted the JAS leadership to issue a clarification the following day, in which it denied 'any relationship with remnants of the former regime' (Al-Marsad al-I'lami al-Islami 2003).

The JAS ideologues appear in many ways obsessed about protecting the ideological purity of the organization as is evident from their writings in the group's journal Majallat Ansar al-Sunnah. On the battlefield, however, this clearly reduced their ability to cooperate and fight together with other Iraqi insurgent groups or under the banner of any coalition. There were apparently internal disagreements in JAS on this, which eventually led to a split in the organization in 2007, when major Sunni Iraqi insurgen groups formed a competing rebel alliance to confront the AQI-led Islamic State of Iraq. By then, AQI had alienated nearly all Iraqi rebel groups by its attempts at dominating the insurgency, encroaching on profitable smuggling routes, and assassinating members of rival groups (Tønnessen 2014; Fishman 2009).

One faction remained committed to the erstwhile hardline platform, condemning any negotiations with the government, while another faction, now operating under the name Ansar al-Sunna-Shariah Council, sought membership in the new anti-ISI rebel alliance, The Reformation and Jihad Front. The hints of a coming split had been around for a while. For example in early 2006, the JAS had to refute reports that it was part of a coalition of Iraqi insurgent groups who had met with US representatives (Jaysh Ansar al-Sunnah 2006).

More generally, JAS spokesmen and its ideologues spoke with somewhat different voices with regard to its adherence to Salafist orthodoxy, Sunni-Shi ite relations, the prioritization of Kurdish nationalism verses global jihad solidarity, etc. For example, in several media interviews attributed to individuals presented as JAS spokesmen and 'emir', there was a certain willingness to make compromises in the interests of Iraqi unity, including even military cooperation with the Shi'ite Mehdi Army (Al-Muharrir Weekly 2004). ${ }^{21}$ However, regarding their relationship with al-Qaida and al-Zarqawi, the JAS spokesman chose to evade the issue, pushing instead the common refrain that the U.S. used the issue of AlQa'ida Organization and Abu-Mus'ab al-Zarqawi [...] as an excuse to target any person or place, level charges at Al-Fallujah, and link events to the 11 September 2001 events' (ibid.). Only during the internal factional crisis in 2007 did the hardliners in JAS feel it needed ISI to fend off internal critics, and in mid-2007 it published statements, supporting 'our brothers' in ISI and claiming joint operations with the group (Parliament of Australia 2009, p. 39). 
These were exceptions, however, and there was very little evidence of a close relationship with al-Qaida in Iraq in JAS' ideological literature. The almost complete absence of references to al-Zarqawi and al-Qaida in their numerous ideological epistles is perhaps the best argument for why it does not make much sense to speak about AI/JAS as simply 'an al-Qaida affiliate' or an al-Zarqawi substructure. If the JAS operated under Zarqawi's command and was loyal to him, one would expect to find on the AI/JAS's websites, at least some of the excessive praise and repetitive pledges of allegiance to al-Zarqawi that inundated pro-Zarqawi web forums at the time. However, this is not the case. In fact, al-Zarqawi, or his organization, have not been mentioned at all, either by name or by his most common aliases, in the JAS' semi-monthly publications, the Majallat Ansar al-Sunnah, of which there were fourteen editions between September 2003 and April 2006, with hundreds of pages of ideological propaganda and theological elaborations in excruciating detail. ${ }^{22}$ Apart from a few military communiqués in late 2004, where the JAS assumed responsibility for joint operations with other Iraqi insurgents, including al-Zarqawi's group, to this author's knowledge, Zarqawi's or his organization's name have not been mentioned in any JAS publication.

In 2010, Ansar al-Islam's historical leadership (Abu Abdallah al-Shafi'i) was captured, striking "great disarray" into the organization (Al-Tamimi 2015). Weakened by counterterrorist operations, defections to rival groups, and intermittent clashes with the Islamic State of Iraq, the AI seemed to face extinction, when in 2011 the U.S. withdrawal of combat troops from Iraq reduced the pressure on the movement. Similar to the ISI, the AI insurgents also benefited from the outbreak of the Syrian civil war. It expanded its activities into several Syrian provinces, especially Idlib and Aleppo, operating under the name, 'Ansar al-Islam in the Levant' often in cooperation with Syrian groups, including Jabhat al-Nusra. In Iraq, however, the group continued to suffer setbacks with continuous leadership losses and defections to the resurgent Daesh organization (ISI's successor group). The latter more or less swallowed the Iraq-based AI organization, after its capture of Mosul in mid-2014 as most AI fighters, probably under some duress, paid allegiance to the new Caliph, installed by Daesh (ibid.). Only towards the end of the 2010s did the AI reemerge as an independent jihadist entity on the Iraqi scene, claiming its first attack in October 2019 after a five year hiatus (Weiss 2019; see also Mu'assasat al-Ansar al-I'lamiyya 2020; Al-Tamimi 2020). Its contempt for ISI and its Daesh successor had by no means diminished:

'their negative impacts on the jihad affected the Ummah in general and not only Jama'at Ansar al-Islam [...] by the grace of God and His preservation of His religion, the Ummah spat them out'. (Al-Tamimi 2020)

\section{The AI/JAS' Role and Ambitions Outside Iraq}

While the term 'al-Zarqawi substructure' has served to obfuscate Ansar al-Islam's identity in Iraq, it has also misrepresented the role played by Ansar al-Islam's networks outside Iraq, and in Europe in particular. There is little doubt that al-Zarqawi's organization had an internationalist orientation in terms of where and against whom it fights. It was implicated in a number of terrorist attacks and terrorist plots outside Iraq, both before and after the US-led invasion of Iraq. The most well-known of these incidents were the assassination of Laurence Foley in Amman in October 2002, the suicide bombings of hotels in Amman in November 2005, and the Katyusha rocket attacks on Eilat and Aqaba in August 2005 (BBC 2002c, 2005, 2006). Al-Zarqawi's network was also implicated in a series of foiled terrorist attacks in several European countries (Nesser 2015, pp. 114-19). Until his death in 2006, al-Zarqawi continuously stressed his ambition to launch operations outside the Iraqi theatre of war, especially against Jewish and Jordanian targets. In a video appearance in April 2006, he famously stated: 'We are in Iraq a stone throw from the al-Aqsa Mosque [in Jerusalem], we are fighting in Iraq, [but] our eyes are on al-Aqsa which will never be freed except with a guiding Qur'an and a prevailing sword' (Shabakat al-Akhbar al-'Alamiyya 2006). In August 2004, for example, communiqués signed by al-Zarqawi's organisation threatened European countries with attacks on their soil if they 
did not withdraw their forces from Iraq. One of the declarations addressed 'the Crusader countries which are conspiring against Islam and are sending forces to Iraq and Afghanistan, especially Italy and Holland' and promised them 'a hell' and 'a bloodbath' unless they heeded 'the lessons of Spain' (Al-Qal'ah Website 2004). The latter was a reference to the Madrid train bombings on 11 March 2004, where Spain suffered its most devastating terrorist attack in its modern history, with as many as 193 fatalities. Another communiqué by al-Zarqawi's network announced that 'all foreigners in Arab Islamic countries' would be targeted, offering them a 17-day deadline for leaving the country before 'painful strikes, one after the other' would commence (Muntadiyat Usama al-Islamiyya 2004).

\section{1. (Alleged) Terrorist Plots by AI/JAS in Europe}

By using terms such as al-Zarqawi 'structure and 'al-Qaida affiliate' when describing the AI/JAS organization, one easily arrives at the conclusion that the presence of its supporters in several European countries presents an immediate terrorist threat. Press reports about foiled terrorist attacks by AI members in 2003 and 2004 have strengthened this impression. By closer inspection, however, these foiled plots are very few, they lack sophistication, and unlike the Zarqawi-linked attacks and plots, they are not claimed by the $\mathrm{AI} / \mathrm{JAS}$ organization and do not appear to be part of a prioritized campaign of international terrorism outside Iraq.

In May 2004 Turkish authorities arrested a group of allegedly AI militants who reportedly plotted to organize attacks during the upcoming NATO summit in Istanbul in June 2004 (Reuters 2004). In another incident in Germany in December 2003, German authorities closed off a Bundeswehr hospital in Hamburg after having received a tip-off from U.S. intelligence sources that 'Islamist suicide attackers of the Ansar al-Islam group' allegedly 'planned a suicide attack with a car bomb' on the hospital or alternatively 'a US military airport' (Financial Times 2003; Spiegel Online 2003). In the latter case, nobody was arrested, however. One year later, in December 2004, AI militants were arrested in Germany on suspicion of planning an assassination attempt of the Iraqi Prime Minister Iyad Allawi during his visit to the country (Der Spiegel 2004a). In August 2005, a video clip was circulated on jihadi websites purportedly showing live training in car bomb explosives at what was claimed to be a JAS 'training camp' in a rural district in Sweden, accompanied by a few statements by 'Mujahideen in Sweden' in support of 'our beloved brothers in Jaysh Ansar al-Sunnah' (Jihad Unspun 2005). Later in Spring 2006, JAS' primary ideological mouthpiece, Majallat Ansar al-Sunna, released a series of articles targeting European, and in particular German, (re-)publishers of the infamous Muhammad cartoons, seemingly threatening attacks beyond the borders of Iraq (Majallat Ansar al-Sunnah 2006a, 2006b; Der Spiegel 2006).

A careful examination of the previously mentioned examples demonstrates, however, a marked difference between these AI/JAS-related incidents on the one hand, and plots and attacks hatched by al-Qaida members and al-Zarqawi operatives during the same period on the other. With regard to the alleged AI plot to bomb the NATO Summit in Istanbul, information was conflicting. There is little doubt that a group of Turkish pro-alQaida militants was apprehended and that much incriminating propaganda and explosive material was found in their houses (e.g., BBC 2004; EurasiaNet 2004; The Scotsman 2004). However, the exact organisational affiliation of jihadi cells was notoriously difficult to pin down, and in 2003-2004, both media sources and government officials tended to use the 'Ansar al-Islam' term as a synonym for Zarqawi's network. While a number of official statements and press accounts referred to the Bursa suspects as Ansar al-Islam members, the fact that all of them appeared to be Turkish nationals sowed doubt upon their affiliation with a group heavily dominated by Iraqi Kurds. True, the AI had sought to reach out to Muslims in Turkey, by, for example, offering 'a Turkish section' of its website (cihad.net 2003). Furthermore, a known Ansar al-Islam facilitator and recruiter, operating out of Italy, Muhammad Majid (also known as Mulla Fu'ad), reportedly had one of his two bases on the outskirts of Istanbul, according to Italian sources (Panorama 2003). Still, there is very 
little evidence of a significant presence of Turkish nationals or Turkish Kurds in the AI movement. Moreover, as far as is known, AI's propaganda never appeared in Kurmanji, the language spoken by Kurds in Turkey.

As the Istanbul bombings of November 2003 had shown, Turkey already had a dedicated network of Turkish jihadis working directly with al-Qaida in Afghanistan (NBC News 2003). Furthermore, it was more likely that Turkish jihadis would link up with al-Zarqawi, who was known to have a network of supporters in Turkey and attracted a steady stream of new foreign fighters, including the perpetrators of the Istanbul attack who fled to Iraq to join Zarqawi's network, not JAS. In fact, by late 2003 JAS apparently no longer attracted many foreign fighters, as it was being overshadowed by al-Zarqawi, the rising star of international jihadism (Al-Tamimi 2015, p. 9).

As for the NATO Summit bomb plotters, it transpired that the apprehended cell was not even linked to AI's international support network. According to Turkish police officials, the cell in Bursa operated independently of the northern Iraqi group, but shared the same ideology and tactics' according to Turkish officials (The Guardian 2004). After the NATO Summit, it turned out that the Turkish authorities were incapable of producing hard evidence for a terrorist conspiracy to undertake its bombing, resulting in the release if many of the suspects. The reason was apparently that it could not be proved beyond doubt that they indeed belonged to the outlawed Ansar al-Islam movement. Turkish police had found much incriminating material, but only at the Bursa cell's hideout, not in Istanbul, and they had not been able to find solid proof of plans to attack the NATO Summit. According to German anti-terrorism officials, many details on the plot indicated 'a rather low professional level on the part of the arrested' (Frankfurter Allgemeine 2004).

The reports on AI's plans for attacking targets in Germany also reveal a lack of strategic determination to launch a terrorist campaign in the West. For example, there was not much more to the alleged AI plot against the Bundeswehr hospital in Hamburg in 2003 than an intelligence tip-off of uncertain reliability. German press sources later understood that the information had been misinterpreted, and the target city was not even Hamburg, but another German city with a similar name. ${ }^{23}$ As for the plot against Prime Minister Allawi during his visit to Germany in 2004, the conspiracy seemed more real. At least in this case there were identifiable suspects and they were apprehended and later stood trial (Los Angeles Times 2005; Voice of America 2009). The plot was said to be 'amateurish' and the plotters' plans 'chaotic' (Der Spiegel 2005). It had clearly not been planned for a very long time. More importantly, the target was an Iraqi one, and did not necessarily signal a strategic decision to launch an all-out war against America's European allies. Furthermore, as opposed to the many pro-al-Zarqawi websites, no online communiqués on $\mathrm{AI} / \mathrm{JAS}$ websites mentioned the plot or threatened a wave of new attacks on the European continent unless they pulled out of Iraq and Afghanistan. When the trial began, it turned out that the three defendants 'have not actually been charged over the suspected plot to kill Allawi' because the plot was too embryonic, and not sufficiently 'advanced to warrant prosecution under German law' (Deutsche Welle 2006). In short, the incident seemed to be an exception to the general rule guiding AI activities in Germany as described by German general prosecutor Kay Nehm at the time:

In Germany, Ansar-al-Islam members are known to be involved in fund-raising campaigns, human trafficking and the forging of passports and other documents [...] So far we have no record of them using force or carrying out assassinations here. (Deutsche Welle 2005)

In a similar vein, U.S. Department of State, when profiling the Ansar al-Islam group in one of its country reports on terrorism, only listed the group's terrorist operations inside Iraq, and described the group's goals as Iraq-focused: 'expelling western interests from Iraq and establishing an independent Iraqi state based on its interpretation of Sharia law' (U.S. Department of State 2015, p. 334). Despite being considered as 'one of the largest Sunni terrorist groups in Iraq', the description of its networks outside Iraq mentioned only 
funding: the group 'receives assistance from a loose network of associates in Europe and the Middle East' (ibid.).

A similar lack of prioritization to wage a war in the West was evident in several statements posted on the website of a group calling themselves 'The Army of Ansar al-Sunnah Brigades in Sweden' in mid- and late 2005. As with many other online communiqués, the significance of such statements is limited in the absence of corroborating evidence. However, during this period, there were clearly JAS sympathizers in Sweden; the country did in fact arrest and convict two Kurds for funding JAS in 2005 (Wollstad 2006). For what it is worth, the group posted various statements, including a video-recorded message and a follow-up communiqué, in which they went to great lengths to emphasize that JAS was not preparing attacks against Sweden or Swedish interests and that 'the people of Sweden [...] should not fear our activities in the country' (Jaysh Ansar al-Sunnah Sweden Website 2005). Their ambitions were only to train cadres for fighting overseas and to punish a Celebrity Pentecostal preacher in Sweden, who had described the Prophet Muhammad as 'a confused pedophile' in one of his sermons, with reference to the Prophet's third marriage to the nine year old Aisha (ibid.; The Christian Science Monitor 2005; Aftonbladet 2005). This blasphemy case did not create much stir internationally, however, in sharp contrast to the Muhammad cartoons published in the Danish Jyllandsposten in late September 2005 and the artworks by Lars Vilks published in a local Swedish newspaper in August 2007, both of which served as pretexts for a number of major terrorist plots (Nesser 2015).

\subsection{Making Sense f AI/JAS International Support Networks}

If the $\mathrm{AI} / \mathrm{JAS}^{\prime}$ role and ambitions outside Iraq were different from that of al-Zarqawi's and al-Qaida, then why and how did the organization operate in the West? There is little doubt that during the 2000s, the AI/JAS had a European-wide network of sympathisers and supporters that assisted the organization in a variety of tasks. These ranged from fundraising, the logistical supply of various equipment, fake ID documents, recruitment, the smuggling of members in and out of Iraq, medical care and safe houses for evacuated fighters, to various propaganda activities, including maintaining the organization's various websites (e.g., Oberlandesgericht München 2006). The AI/JAS had reportedly its largest support infrastructure in Germany and Italy, but it also had a number of supporters in Sweden, Norway, Spain, Great Britain and other European countries (e.g., Steinberg 2008).

Such activities were not innocuous and could have very deadly outcomes in conflict zones. Several court cases against AI/JAS supporters have revealed that money collected in Europe had been used to finance JAS operations in Iraq. One fundraising case involved some USD 148,000 collected in Sweden between autumn 2002 and mid-April 2004, and which went partly to fund the catastrophic suicide bombings of the PUK and KDP headquarters in Irbil in February 2004 (Wollstad 2006).

Furthermore, the repeated discovery of jihadi support networks in Europe since the 1990s, prompted fears that these networks would somehow mutate into operative terrorist cells targeting their host states in the West. The notion of 'mutating cells' gained some credence since many jihadi attack cells were known for their involvement in logistical activities prior to, or even during, their preparations to mount violent operations (Nesser 2015). When governments previously had assumed that there existed a sort of 'gentlemen's agreement' that militants residing in Europe 'would abstain from carrying out attacks' and only 'limit themselves to logistic activities', there was a growing realization, many observed that '[i]f you consent to logistic activities, sooner or later you expose yourself to those of terrorism' (Allam 2003). Or at least, this was a common narrative, pushed by authoritarian Middle Eastern governments who wished Europe to be more cooperative in expelling emigré opposition figures, both militants and moderates.

\section{Conclusions}

The AI/JAS case explored in this study suggests that the 'mutating cell'-thesis is only relevant for a relatively distinct form of militant Islamist groups. As shown in this case 
study, the AI/JAS cannot be described as 'moderate' in any meaningful sense, based on their operational patterns and embracing of violent tactics in Iraq. Nor does the group operate outside the hardline salafi-jihadi scene. In fact, the overlap with al-Qaida along ideological and behavioural dimensions is so significant that many observers have concluded that $\mathrm{AI} / \mathrm{JAS}$ was closely associated with al-Qaida. And yet, as the analysis has demonstrated, the AI/JAS did not merge with AQI and ISI, nor did it embrace international terrorist plotting as a main priority area. This despite the group and its predecessors having longstanding logistical support networks in Europe going back to the early the 1990s. There have been no clear signs that the organization made preparations for a terrorist campaign in Europe. Hence, this demonstrates the limited validity of the 'mutating cell'-thesis, as it does not even cover cases of hardline Salafist-jihadist groups, hosting foreign fighters, employing suicide operations and fighting western forces overseas.

The AI/JAS case is not an aberration, however. The recent decade of Islamic State (or ISIS, Daesh) terrorism has perhaps blinded us to the fact that most militant Islamist groups, despite their violent rhetoric and posturing, have resisted adopting al-Qaida's and ISIS' global jihad strategy, insisting instead that the struggle against the local and near enemy should have priority, not that against the West. Why is this the case?

One reason is clearly the vulnerability of insurgent support networks in the West. As opposed to the various al-Qaida and ISIS inspired cells that have plotted attacks in Europe over the past decades, the AI/JAS organisation in exile appears to be relatively structured and identifiable. For example, the investigations into AI/JAS structures in Sweden and Germany revealed that the organisational structures were indeed hierarchical (Gude 2004). In Germany, investigators had identified six hierarchically organized levels: the 'company director' and his 'deputy director' in Iraq at the top; the 'engineers' whom included leading cadres in Iran, in Afghanistan and in Kuwait; and the mid-level commanders, called 'foremen' and 'governors' (this included the head of AI's base in Stuttgart, Ata Abdoulaziz Rashid, who stood trial following the Alawi plot in 2004). Finally, at the bottom were 'employees' and 'workers', who were supporters, fighters or suicide recruits (ibid.; Der Spiegel 2004b). Similarly, a more recent Italian investigation into the Rawti Shax organization, the European-wide militant Kurdish movement established and run by AI's original founder Mullah Krekar, which reportedly included some former AI members, was also very hierarchical (BBC 2015). The various departments were tightly run by the top emir and his lieutenants, each overseeing specialised units and sections. Rawti Shax was suspected of serving as a political front for al-Qaida's Kurdistan Brigades (AQKB), a small outfit operational in Iraqi Kurdistan only between 2007 and 2012 (Västmanslands Tingsrätt 2012; Khalil 2007b). ${ }^{24}$ According to Krekar, however, Rawti Shax was slated to become 'an armed Islamic group' only at some point in the future (Krekar 2015).

Krekar might have hoped that his network would evade a crackdown, given their low profile and modest short-term ambitions. However, after receiving a Supreme Court expulsion verdict in 2007 and his imprisonment in Norway in 2012, inter alia for issuing death threats to the former Prime Minister, he grew increasingly frustrated by his inability to operate freely and develop his organization. He began urging his closest followers, during their frequent meetings in the prison's visitor section, to start planning demonstrations and various acts of violence to put pressure on Norwegian authorities to have him released. This included 'hostile activities against diplomats from Norway and the United Kingdom, to be carried out in the Middle East', according to Italian investigators (cited in CNN 2015). Hence, what apparently galvanized Krekar and the Rawti Shax into violent action was the very prevention of their diaspora-based support activities for a future jihadist project in Kurdistan, not a strategy for global jihad on European continent. In October 2015, more than a dozen Rawti Shax members were arrested on terrorism charges, nearly all of them Iraqi Kurds.

Given the vulnerability of such hierarchical structures, insurgent supporters operating in exile will go to great lengths to minimize risks, enmeshing such activities in legitimate humanitarian, human rights and political activism. In a rational choice analysis, violent 
plotting only makes sense when support activities are of little importance or have been suppressed by host states (Lia and Kjøk 2001).

At the same time, while hierarchical movements for mobilizing support are relatively easy targets for intelligence detection, monitoring and surveillance, small self-radicalised autonomous cells, operating with a very tight security protocol, are not very useful for raising funds or recruiting foreign fighters. They cannot offer the kind of external logistical support that the AI/JAS insurgents in Iraq needed. This dilemma is especially hard to resolve for salafi-jihadi insurgents given their ideological commitment to a global struggle. For the AI/JAS in the mid-2000s the solution was not difficult. Although several European countries had significant success in penetrating AI networks on their territory, they all faced serious legal challenges in the prosecuting of individuals for supporting insurgencies overseas. Although AI/JAS saw a few members arrested and prosecuted in Europe, they represented only a tiny majority in the European-wide networks, which were estimated at several hundred in Germany alone.

This article is a plea for greater attention to the diversity of local jihadi groups, including a greater focus on the empirical investigation of their history, ideological programs, and behavioural and operational characteristics. The case of AI/JAS highlights how a group widely accepted as an al-Qaida affiliate and an al-Zarqawi creature simply fails to correspond to the accepted narrative, and challenges us to rethink established categories and labels.

The policy implications for these findings are several. Hence, while the AI/JAS in the mid-2000s was clearly a serious threat to the stability of Iraq, it did not present an immediate terrorist threat to Europe and the outside world. While European governments should fulfil their international obligations with regard to suppressing illegal fundraising, they would be ill-advised to equate AI/JAS sympathizers and operative al-Qaida/ISIS cell members in terms of the prioritization of investigative resources. Secondly, this case study also underlines the importance of making better sense of what linkages between different jihadi groups actually imply in practice. Understanding the complexities and nuances in patterns of contacts and cooperation between militant Islamist extremists, based on scattered pieces of information of varying reliability will always be a daunting challenge.

Funding: This research received funding from Research Council Norway project No. 263017/F10 ("Rebel Governance in the Middle East").

Acknowledgments: I would like to thank Petter Nesser, Truls Hallberg Tønnessen, Anne Likuski, Thomas Hegghammer, Mohammed M. Hafez and two anonymous reviewers for constructive and insightful comments on earlier drafts of this article.

Conflicts of Interest: The author declares no conflict of interest.

\section{Notes}

His real name was Ahmad Fadil Nazzal Al-Khalaylah.

An investigator cited by the German Focus magazine, stated that "Ansar al-Sunna [...] can hardly be distinguished from the terrorist Al-Zarqawi troop" (Gude 2005). Likewise, the German Der Spiegel referred to the various networks run by AI or JAS sympathisers and supporters in Europe as "part of the underground structure of top terrorist Abu Musab al-Zarqawi" (Der Spiegel 2004b).

3 It was listed by the UN and the EU already in February 2003 (AI) and March 2004 (JAS) (United Nations 2006, p. 34; Internationella åklagarkammaren i Stockholm 2005, p. 2).

4 Al-Zarqawi's group changed its name from Jama'at al-Tawhid wa'l-Jihad to Tanzim Qa'idat al-Jihad fi Bilad al-Rafidayn (usually translated as al-Qaida in Iraq (AQI)) in late 2004, and later, in 2006, to the Islamic State of Iraq (ISI).

5 For important contributions on the global vs. local jihad debate, Gerges (2005) and Hegghammer (2011).

6 E.g., the Salafist Group for Preaching and Combat (GSPC) in Algeria and Al-Zarqawi's Unity and Jihad Group (TWJ) in Iraq were accepted into the fold, while the Fatah al-Islam militants in Lebanon were rebuffed when seeking al-Qaida's endorsement for membership (Interview. 2008. European Intelligence Official, Responsible for Monitoring Jihadist Movements in the Levant. Interview by author. Date and location withheld on request). 
Not entirely clear when Krekar ceased to be the emir of Ansar al-Islam. He has claimed in court that he had no role after May 2002, but he seems to have acted as if he was still the emir until early 2003 in media interviews and Ansar al-Islam Website statements (see e.g., Ansar al-Islam Website 2003f).

8 Kurdish authorities reported the perpetrators to be Ansar al-Islam operatives, although the only captive among the would-be assassins told reporters that he was an AI sympathiser, acting on his own. His motive for killing Salih was typical for jihadist militants: the PM was 'an infidel', a Westernized politician, who had been 'watered like a plant by U.S. policies' (McKiernan 2002). For example, a list of top AI leadership figures (16 men) reveals that most of them Kurds, with only one person said to be an Arab, living in Baghdad (Sorany 2012, p. 240).

Krekar said in the interview: "the jihadi arena [in Kurdistan] lacks jihadi leaders and senior operatives because most of these fine men emigrated to the Sunni triangle in order to form the spear's head in the face of the occupation and hence, our arena was left empty. And when we asked that they returned some of their leaders and some of their trained youth to Kurdistan, they responded that their positions/presence in the Sunni Iraqi triangle has attained such a strategic importance that it was difficult for them to leave. [they said]: It is necessary to be patient until the occupation forces have left" (time: 26:30-27:25). Author's translation. (Ansar Media Center's Website 2010, audiofile: 26:30-27:25).

For example, it starts out by citing a typical Salafist formulation that 'the worst of things are renewals [of the Qur'an and the Prophetic Traditions], any renewal is innovation (bid'ah), innovation leads astray (dalala) and everything that leads astray ends up in hell (kull dalala fi al-nar)'. Similarly, it also condemns 'those who deviate and suspend, in the name of interpretation, what has been elaborated in the books of the virtuous forefathers (al-salaf al-salih)' (cited in Ansar al-Islam Website 2003g).

As part of the justification for this position, the Shura Council referred to the practices of the Prophets as retold in several 'true hadiths' of 'dispatching assassination squads against the infidel parties, for example against Basmat bint Marwan al-Khatmiyya who was causing harm to God's Prophet, against Ka'b bin al-Ashraf and many others' (cited in Ansar al-Islam Website 2003c). Not surprisingly, these theological arguments were more or less copied from Shaykh Ibn Taymiyya's writings (his book al-Sarim al-Maslul), who is without doubt the most important medieval Islamic theologian for modern-day jihadis.

In fact, already in 2002, well before the March 2003 invasion of Iraq, U.S. Secretary of Defence Donald Rumsfeld, the Joint Chiefs of Staff and the CIA director had pressed for military operations against what they believed were 'Al-Qaida members' and 'chemical weapons facilities' in Khurmal, allegedly controlled by Ansar al-Islam (Rumsfeld 2011, p. 447). By mid-2002, the existence of such plans was already circulating in the media (BBC 2002b). Rumsfeld admitted in his memoirs that the intelligence was not 'conclusive' (Rumsfeld 2011, p. 447). In fact, it turned out that the district and town of Khurmal was controlled by Komala Islami, a small pro-Iranian Islamist group in opposition to AI (New York Times 2003b). Still, the Bush administration has much criticized for not striking against suspected Zarqawi hideouts in Northern Iraq prior to the invasion, prioritizing instead regime change over 'removing' dangerous terrorists (Benjamin 2004).

His real name was Mustafa bin Abd al-Qadir Sethmarian Nasar. The most comprehensive biography on Nasar is Lia (2008).

Yasin al-Bahr was his kunya in Kurdistan. His real name was Suhayl bin Jasim al-Sahli. Another of his kunyas was Abu al-Shahid al-Sharqi.

According to one study, citing reports by inhabitants in Ansar controlled villages on the Iraqi-Iranian border claimed that that "Iran now allows Ansar al-Islam to operate from safe houses in adjacent Iranian towns such as Mariwan. In other cases, Iranian authorities held Ansar militants for a few days and then brought them back to the border, returned their weapons to them, and allowed them to reenter Iraq." Cited in (Romano 2007, pp. 13, 18).

A suicide attack by AI was narrowly foiled in 2002 when a 19-year old Kurdish AI-recruit, Didar Khalid Khedr, failed to detonate his device outside a peshmerga headquarter in the town of Sayid Sadiq (The Sydney Morning Herald 2002). German Prosecutors via Telephone. Interview by author. Date not recorded.

The Department of Treasury's statement on Krekar suggested, at least implicitly, that Krekar continued to actively travel to Europe and Iraq for fundraising and recruitment purposes, while in fact, he did not leave Norway since his repatriation in January 2003. In particular, it stated that "Krekar has visited Germany several times and during these trips conducted fundraising for AS and performed logistical activities", which makes little sense in view of the fact that Jaysh Ansar al-Sunnah was formed only in late 2003 (U.S. Department of the Treasury 2006).

Interview. 2005. European Intelligence Official, Responsible for Monitoring the JAS and the al-Zarqawi Group in Iraq. Interview by author. Date and location withheld on request.

In an interview with the Beirut-based weekly Al-Muharrir in August 2004, a person identified as Abu al-Hasan, presented as the JAS 'emir' spoke openly about their cordial relationship with the Mehdi Army, the Shi' ite militia of Muqtada Sadr: 'We exchanged mujahidin with Al-Sayyid Muqtada. We sent him about 200 of our mujahidin and he sent 250 of the Al-Mahdi Army mujahidin to Al-Fallujah. Therefore, the relationship can be described as intimate. [...] Our conditions are full withdrawal from all the Iraqi territories from the north to the south and compensation of every family in our beloved Iraq for the loss or injury of its children or honor and the destruction of their homes, provided that all Iraqi prisoners are set free and the Islamic laws are respected. The resistance men should avoid worldly posts. This is done in accordance with the agreement signed with Al-Sayyid Muqtada al-Sadr'. Cited in Al-Muharrir Al-Muharrir Weekly (2004). 


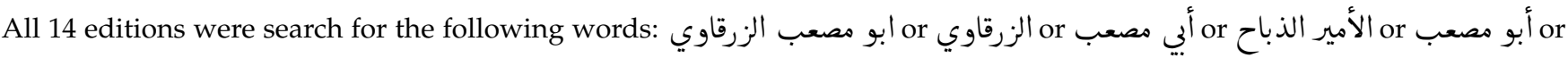
قاعدة الجهاد في بادة الرافة التوحيد والجهاد or قافين.

Interview. 2006. German Journalist Covering Terrorism Issues in Germany. Interview by author. London. April 28.

German Prosecutors via Telephone. Interview by author. Date not recorded.

\section{References}

Abedin, Mahan. 2004. Analyzing Ansar al-Islam. Terrorism Monitor 2: 4-6. Available online: https://web.archive.org/web/2006032108 2438/www.jamestown.org/images/pdf/ter_002_011.pdf (accessed on 15 December 2021).

Accord. 2006. Report by Austrian Centre for Country of Origin and Asylum Research and Documentation. No. a-4812 (ACC-IRQ-4812), March 8. Available online: https:/ /www.ecoi.net/en/document/1037043.html (accessed on 7 February 2022).

Aftonbladet. 2005. Runar går till Attack mot Islam [Runar Attacks Islam], April 19. Available online: https://web.archive.org/web/20 050419083742/http:/ / www.aftonbladet.se/vss/nyheter/story/0,2789,633287,00.html (accessed on 8 February 2022).

Al-Adl, Sayf. 2005. The Jihadi Life Story of Commander "The Slaughter" Abu Mus'ab al-Zarqawi. Muntadayat al-Hikma Webforumm May 25. Available online: http:/ / www.hkmah.net/showthread.php?t=8118 (accessed on 1 June 2005). (In Arabic)

Al-Hesbah.org. 2006. Important Communiqué from the Society of Ansar al-Sunnah. Signed by the Society of the Ansar alSunnah/Majlis al-Shura, May 3. Available online: www.al-hesbah.org/v/ (accessed on 1 June 2006).

Allam, Magdi. 2003. Cooperatives of Radical Islam. La Repubblica, June 25, pp. 1-2. (In Italian)

Al-Marsad al-I'lami al-Islami. 2003. Clarification. The Ansar al-Sunnah Army Information Department, October 6. (In Arabic)

Al-Muharrir Weekly. 2004. Interview with Abu-Abdallah al-Hasan Bin-Mahmud, Identified only as Abu-al-Hasan, the 'Amir' of the Ansar al-Sunnah Army in Iraq, by Dr Ahmad Nayif al-Dulaymi 'in the den of the Iraqi Resistance'. Al-Muharrir Weekly, August 21-27.

Al-Qal'ah Website. 2004. 'Communiqué to Europe from the Media Unit of Jama'at al-Tawhid al-Islamiyya, August 15. Available online: www.qal3ati.net/vb/showthread.php?t=113534 (accessed on 19 January 2005). (In Arabic)

Al-Tamimi, Aymenn Jawad. 2015. A Complete History of Jamaat Ansar al-Islam. aymennjawad.org, December 15. Available online: https:/ / www.aymennjawad.org/2015/12/a-complete-history-of-jamaat-ansar-al-islam (accessed on 15 December 2021).

Al-Tamimi, Aymenn. 2017. The Islamic State and the Kurds: The Documentary Evidence. CTC Sentinel 10: 33-38.

Al-Tamimi, Aymenn. 2020. Interview with Jama'at Ansar al-Islam, August 23. Available online: https://www.aymennjawad.org/2020 /08/interview-with-jamaat-ansar-al-islam (accessed on 9 February 2022).

Ansar al-Islam Website. 2003a. A Portrait of the Ansar al-Islam Group. Available online: www.navend.com/ansar_taref.htm (accessed on 1 March 2005). (In Arabic)

Ansar al-Islam Website. 2003b. Call to the Muslims. Available online: https:/ /web.archive.org/web/20030428230800/http:/ / 66.246.51. 215/neda_moslmin.htm (accessed on 1 March 2005). (In Arabic)

Ansar al-Islam Website. 2003c. Communiqué by the Shura Council of Ansar al-Islam in Kurdistan on the Killing of the Imams of Unbelief, February 18. Available online: https://web.archive.org/web/20030501192828/http://66.246.51.215/shawgard.htm (accessed on 28 August 2003). (In Arabic)

Ansar al-Islam Website. 2003d. Communiqué from the Ansar al-Islam's Military Committee, March 22. Available online: https: / / web.archive.org/web/20030413073242/http:/ /66.246.51.215/defg.htm (accessed on 25 August 2003). (In Arabic)

Ansar al-Islam Website. 2003e. Here Are Some of the Names of the Arab Brothers Who Were Martyred Recently in the Land of Iraqi Kurdistan and Joined the Martyrs' Caravan. Available online: www.yasean.8m.com/shohada.htm (accessed on 12 August 2003). (In Arabic)

Ansar al-Islam Website. 2003f. Mulla Krekar: The 8 February Operation Was a Security Operation in Response to Talebani's Attempts to Split the Ansar al-Islam, February. Available online: https:/ /web.archive.org/web/20030301231540/www.ayobi.com/article. php?sid=105 (accessed on 1 March 2005).

Ansar al-Islam Website. 2003g. Our Doctrine and Program, August. Available online: www.navend.com/aqeda.htm (accessed on 1 March 2005). (In Arabic)

Ansar al-Islam Website. 2003h. Sheltering Mujahidin. Available online: https:/ / web.archive.org/web/20030428230157/http:/ /66.246 $.51 .215 /$ mashroe.htm (accessed on 1 March 2005). (In Arabic)

Ansar al-Islam Website. 2003i. The Martyrs of Iraqi Kurdistan: The Emir of the Arab Mujahidin in the Ansar al-Islam Group in Iraqi Kurdistan. Available online: www.yaesean.8m.com (accessed on 12 August 2003). (In Arabic)

Ansar al-Islam Website. 2003j. The Perpetrator of the Martyrdom Operation Which Killed the Australian Journalist, April 30. Available online: https:/ / web.archive.org/web/20030602192647/www.ayobi.com/index.php (accessed on 21 March 2005). (In Arabic)

Ansar Media Center's Website. 2010. Meeting with the Distinguished Mala Karikar, One of the Founders of the Ansar al-Islam Group. Audiotaped and Transliterated Interview. Available online: https://web.archive.org/web/20110704225803/http: / / ansarcenter.net/lqa.html (accessed on 10 June 2010). (In Arabic)

Apostolou. 2004. Who Lost Zarqawi? The True Intelligence failure. National Review Online, November 2. Available online: https: / / web.archive.org/web/20041102233517/www.nationalreview.com/comment/apostolou200411020824.asp (accessed on 10 June 2010). 
Awena. 2006. Al-Zarqawi Was the Mastermind of the Attack on Dr Barham. Translated from Sourani by BBC Monitoring. Awena, February 28.

Bacon, Tricia. 2018. Why Terrorist Groups Form International Alliances. Philadelphia: University of Pennsylvania Press.

Bakawan, Adel. 2017. The Generations of Jihadism in Iraqi Kurdistan. Notes de l'Ifri. Paris: French Institute of International Relations (IFRI). Available online: https://www.ifri.org/sites/default/files/atoms/files/bakawan_jihadism_iraqi_kurdistan_2017.pdf (accessed on 15 December 2021).

BBC. 2002a. Iraqi Kurdish Leader Evades Assassins, April 3. Available online: http://news.bbc.co.uk/2/hi/middle_east/1909073.stm (accessed on 15 December 2021).

BBC. 2002b. FBI Questions Iraqi Kurd Militant, September 27. Available online: http://news.bbc.co.uk/2/hi/middle_east/2285703.stm (accessed on 15 December 2021).

BBC. 2002c. Jordan Arrests Two for Diplomat's Killing, December 14. Available online: http://news.bbc.co.uk/2/hi/middle_east/25 75879.stm (accessed on 6 December 2005).

BBC. 2004. Turkey “Foils Nato Summit Attack”, May 3. Available online: http://news.bbc.co.uk/2/hi/europe/3679751.stm (accessed on 6 December 2005).

BBC. 2005. Zarqawi ‘Link to Jordan Rockets', August 24. Available online: http://news.bbc.co.uk/2/hi/middle_east/4179522.stm (accessed on 3 May 2006).

BBC. 2006. Hotel Bomb Trial Starts in Amman, April 24. Available online: http://news.bbc.co.uk/2/hi/middle_east/4939910.stm (accessed on 3 December 2006).

BBC. 2007. Iraq's Other Kurdish Rebel Group, December 19. Available online: http://news.bbc.co.uk/1/hi/world/middle_east/7148 405.stm (accessed on 8 February 2022).

BBC. 2015. Jihadist Cell in Europe 'Sought Recruits for Iraq and Syria', November 12. Available online: https://www.bbc.com/news/ world-europe-34802317 (accessed on 15 December 2021).

Benjamin, Daniel. 2004. Holy Zarqawi: Why Bush let Iraq's top Terrorist Walk. Slate Magazine, October 29. Available online: www.slate.com/id/2108880/ (accessed on 15 December 2021).

Brisard, Jean-Charles, and Damien Martinez. 2005. Zarqawi: The New Face of al-Qaeda. Cambridge: Polity Press.

Byman, Daniel. 2014. Buddies or Burdens? Understanding the Al Qaeda Relationship with Its Affiliate Organizations. Security Studies 23: 431-70. [CrossRef]

Celso, Anthony. 2014. Al-Qaeda's Post 9/11 Devolution: The Failed Jihadist Struggle against the Near and Far Enemy. New York and London: Bloomsbury.

cihad.net. 2003. Ensar el-Islam Türkça Bölimi. Available online: www.cihad.net/main.html (accessed on 12 August 2003).

CNN. 2015. 15 Arrested in European Sweep Against Ansar al Islam Offshoot, Police Say, November 12. Available online: https: / / edition.cnn.com/2015/11/12/europe/europe-terror-plots-arrests/ (accessed on 8 February 2022).

Dagbladet. 2002. Ofret i Storpolitisk Spill, October 9. Available online: https://www.dagbladet.no/nyheter/ofret-i-storpolitisk-spill/ 65841589 (accessed on 7 February 2002).

Darling, Dan, and Rohan Gunaratna. 2004. Ansar al-Islam Dossier. Center for Policing Terrorism “CPT", July 30. Available online: https:/ / web.archive.org/web/20060104075810/www.cpt-mi.org/Ansar\%20al-Islam\%20Final.pdf (accessed on 15 December 2021).

Der Spiegel. 2004a. Attentatspläne Gegen Alawi: BGH Erlässt Haftbefehl Gegen Zwei Terrorverdächtige, December 4. Available online: https:/ / www.spiegel.de/politik/deutschland/attentatsplaene-gegen-alawi-bgh-erlaesst-haftbefehl-gegen-zweiterrorverdaechtige-a-331049.html (accessed on 5 December 2005).

Der Spiegel. 2004b. The Third Generation. Der Spiegel, December 13. (In German)

Der Spiegel. 2005. Jihad Dinner: Chief Prosecutor Intends to Indict Three Men for Planning to Assassinate Former Iraqi Prime Minister in Berlin, but Plans Appear to Have Been Rather Chaotic. Der Spiegel, September 6. (In German)

Der Spiegel. 2006. Online Magazine Hints at Attacks on Papers that Ran Muhammad Caricatures, May $5 . \quad$ Available online: https://www.spiegel.de/international/spiegel/militant-islam-online-magazine-hints-at-attacks-on-papers-that-ranmuhammad-caricatures-a-414625.html (accessed on 15 December 2021).

Deutsche Welle. 2005. Germany Examines Allawi Assassination Plot, December 7. Available online: https://www.dw.com/en/ germany-examines-allawi-assassination-plot/a-1420935 (accessed on 15 December 2021).

Deutsche Welle. 2006. Iraqis Accused of Terror Plot Silent as Trial Begins in Germany, June 26. Available online: https: / www.dw.com/ en/iraqis-accused-of-terror-plot-silent-as-trial-begins-in-germany/a-2063017 (accessed on 15 December 2021).

EurasiaNet. 2004. Turkish Officials Foil Terrorist Plot to Strike Upcoming Nato Summit in Istanbul, May 3. Available online: https: //web.archive.org/web/20040607021205/https:/ / eurasianet.org/departments/insight/articles/eav050304a.shtml (accessed on 3 June 2005).

Farrall, Leah, and Mustafa Hamid. 2015. The Arabs at War in Afghanistan. London: Hurst.

Financial Times. 2003. Hamburg Hospital Sealed Off after Bomb Warning. Financial Times, December 31.

Finlayson, Kenneth. 2005. Operation Viking Hammer: 3/10 SFG against the Ansar Al-Islam. Veritas 1: 15-19. Available online: https://arsof-history.org/articles/v1n1_op_viking_hammer_page_1.html (accessed on 15 December 2021). 
Fishman, Brian. 2009. Dysfunction and Decline: Lessons Learned from Inside Al-Qa'ida in Iraq. West Point: Combating Terrorism Center. Available online: https:/ / www.ctc.usma.edu/dysfunction-and-decline-lessons-learned-from-inside-al-qaida-in-iraq/ (accessed on 15 December 2021).

Fishman, Brian. 2016. Revising the History of Al-Qa'ida's Original Meeting with Abu Musab al-Zarqawi. CTC Sentinel 9: $28-33$.

Frankfurter Allgemeine. 2004. German Assumed to Have Fallen Victim to Terrorist Attack. Frankfurter Allgemeine, June 22. (In German) Gerges, Fawas A. 2005. The Far Enemy: Why Jihad Went Global. Cambridge: Cambridge University Press.

Goldberg, Jeffrey. 2002. The Great Terror. The New Yorker, March 17. Available online: https://www.newyorker.com/magazine/2002/0 $3 / 25$ /the-great-terror (accessed on 2 December 2005).

Goldberg, Jeffrey. 2003. The Unknown: The C.I.A. and the Pentagon take another look at Al Qaeda and Iraq. The New Yorker, February 10 .

Gude. 2004. E-Mails to the "Company"; German Security Authorities Cracked the Secret Code of the Terror Organization Ansar al-Islam [original in German]. Focus, December 20, pp. 48-50.

Gude, Hubert. 2005. Cruel Specialty. Focus, February 22, Obtained via Foreign Broadcast Information Service.

Hafez, Mohammed. 2007. Suicide Bombers in Iraq: The Strategy and Ideology of Martyrdom. Washington, DC: United States Institute of Peace Press.

Hafez, Mohammed M. 2020. The Crisis Within Jihadism: The Islamic State's Puritanism vs. Al-Qa'ida's Populism. CTC Sentinel 13: 40-46.

Hamming, Tore Refslund. 2019. Global Jihadism after the Syria War. Perspectives on Terrorism 13: 1-16.

Hayes, Stephen F. 2004. The Connection: How al Qaeda's Collaboration with Saddam Hussein Has Endangered America. New York: HarperCollins.

Hayes, Stephen F., and Thomas Joscelyn. 2005. Another Link in the Chain: The Role of Saddam and al Qaeda in the Creation of Ansar al Islam. Weekly Standard, July 22. Available online: https:/ / web.archive.org/web/20050725001521/http:/ / www.weeklystandard. com/Content/Public/Articles/000/000/005/860ydczr.asp (accessed on 15 December 2021).

Hegghammer, Thomas. 2007. Combattants saoudiens en Irak. Cultures $\mathcal{E}$ Conflits 64: 111-26.

Hegghammer, Thomas. 2011. The Rise of Muslim Foreign Fighters: Islam and the Globalization of Jihad. International Security 35: 53-91. [CrossRef]

Human Rights Watch. 2003. Ansar al-Islam in Iraqi Kurdistan. Available online: www.hrw.org/backgrounder/mena/ansarbk020503. htm (accessed on 15 December 2021).

Husayn, Fu'ad. 2005. Al-Zarqawi: The Second Generation of Al-Qa'ida. English Translation. Available online: http://atc2005.blogspot. com/2006/06/al-zarqawi-second-generation-of-al.html (accessed on 15 December 2021).

International Crisis Group. 2003. Radical Islam in Iraqi Kurdistan: The Mouse That Roared? Middle East Briefing No. 4, February 7. Available online: https:/ / www.crisisgroup.org/middle-east-north-africa/gulf-and-arabian-peninsula/iraq/radical-islam-iraqikurdistan-mouse-roared (accessed on 15 December 2021).

Internationella åklagarkammaren i Stockholm. 2005. Ansökan om stämning. [Application for summons] Ali Kamal Berzengi and Ferman Jabbar Abdulla, Stockholm. Document No. C09-2-302-04. Internationella åklagarkammaren i Stockholm, April 4.

Jackson, Richard. 2007. Constructing Enemies: 'Islamic Terrorism' in Political and Academic Discourse. Government and Opposition 42: 394-426. [CrossRef]

Jalal, Pishtiwan, and Ariel I. Ahram. 2021. Salafism, Sectarianism, and National Identity in Iraqi Kurdistan. The Middle East Journal 75: 386-406. [CrossRef]

Jaysh Ansar al-Sunnah. 2006. A Statement from Ansar al-Sunnah Army Denying Any Talks with the American Forces. Signed The Commander of the Ansar al-Sunnah Army. Jaysh Ansar al-Sunnah, February 20.

Jaysh Ansar al-Sunnah Sweden Website. 2005. Untitled communiqué. Signed Abi Abdillahi Dahir, Military Division, Jaish Ansar Al-Sunnah, September 23. Available online: http://mypetjawa.mu.nu/archives/jaish_ansar_al_sunnah_sweden_website.htm (accessed on 15 May 2006).

Jaysh Ansar al-Sunnah Website. 2004a. Communiqué by the Ansar al-Sunnah Army Command to the People of Islam about the Faluja Events, November 11. Available online: www.ansar-army00.5u.com/falwja.htm (accessed on 15 December 2004). (In Arabic)

Jaysh Ansar al-Sunnah Website. 2004b. The Elections: A Religious-Juridical Assessment, November 18. Available online: https: //web.archive.org/web/20041208133649/www.ansar-army00.5u.com/Entekabat.htm (accessed on 1 December 2004). (In Arabic)

Jaysh Ansar al-Sunnah Website. 2004c. A Special Congratulation from the Ansar al-Sunnah Army to the Monotheism and Jihad Group on the Occasion of Its Inclusion on the List of Terrorists, October 18. Available online: www.ansar-army00.5u.com/Tahneaa.htm (accessed on 3 December 2004). (In Arabic)

Jaysh Ansar al-Sunnah Website. 2004d. Seizing Control Over the al-Ghazaliyyah Region and Striking a Group of the Feminine Guard in a Joint Operation between the Ansar al-Sunnah Army and the Society of Qa'idat al-Jihad, November 10. Available online: www.ansar-army00.5u.com/gazalyaa.htm (accessed on 3 December 2004). (In Arabic)

Jaysh Ansar al-Sunnah Website. 2004e. Joint Operation between the Islamic Army in Iraq, Qa'idat al-Jihad and the Ansar al-Sunnah Army in Seizing Control Over the Court in al-Yusufiyyah, November 11. Available online: www.ansar-army00.5u.com/yousfea. htm (accessed on 3 December 2004). (In Arabic) 
Jaysh Ansar al-Sunnah Website. 2004f. Clarification Regarding the Communiqués and Positions Which Have Been Attributed to the Ansar al-Sunnah Army, April 8. Available online: www.ansar-army00.5u.com/tawdee7.htm (accessed on 3 December 2004). (In Arabic)

Jihad Unspun. 2005. Statement from Mujahideen in Sweden, September 24. Available online: www.jihadunspun.com/intheatre_ internal.php?article $=104453 \&$ list $=$ /home.php\& (accessed on 2 May 2006).

Kahler, Miles. 2010. Collective Action and Clandestine Networks: The Case of Al Qaeda. In Networked Politics: Agency, Power, and Governance. Edited by Miles Kahler. Ithaca: Cornell University Press, pp. 103-24. [CrossRef]

Kakei, Saed. 2013. The Islamic Movement of Kurdistan: From Conflict to Cooperation. Ekurd.net, March 25. Available online: http:/ / www.ekurd.net/mismas/articles/misc2013/3/state6950.htm (accessed on 2 January 2022).

Katzman, Kenneth. 2008. Al Qaeda in Iraq: Assessment and Outside Links. Washington, DC: Congressional Research Service, August 15. Available online: https://www.everycrsreport.com/files/20080815_RL32217_c6aad430c7e11c2eeb3c9f3ca274bf6323735e73.pdf (accessed on 15 December 2021).

Khalil, Lydia. 2005. The Transformation of Ansar al-Islam. Terrorism Monitor 3: 4-6. Available online: https://web.archive.org/web/20 060106021638/www.jamestown.org/terrorism/news/uploads/ter_003_024.pdf (accessed on 15 December 2021).

Khalil, Lydia. 2007a. The Hidden Hand of Iran in the Resurgence of Ansar al-Islam. Terrorism Monitor, June 7.

Khalil, Lydia. 2007b. The Kurdistan Brigades: Al-Qaeda's Kurdish Henchmen. Terrorism Focus, May 14. Available online: https: //jamestown.org/program/the-kurdistan-brigades-al-qaedas-kurdish-henchmen/ (accessed on 8 February 2022).

Krekar, Mullah. 2004. Med Egne Ord [In My Own Words]. Oslo: Aschehoug.

Krekar, Mullah. 2015. Rawts Interne Regler og Program [Rawt's Internal Regulations and Program]. Krekar's Defense Team, January 30. (In Sourani)

Lahoud, Nelly, Stuart Caudill, Liam Collins, Gabriel Koehler-Derrick, Don Rassler, and Muhammad al-'Ubaydi. 2012. Letters from Abbottabad: Bin Ladin Sidelined? West Point: Combating Terrorism Center. Available online: https://www.ctc.usma.edu/lettersfrom-abbottabad-bin-ladin-sidelined/ (accessed on 15 December 2021).

Lia, Brynjar. 2008. Architect of Global Jihad: The Life of Al-Qaida Strategist Abu Mus'ab Al-Suri. New York: Columbia University Press.

Lia, Brynjar. 2016. Jihadism in the Arab World After 2011: Explaining Its Expansion. Middle East Policy 23: 74-91. [CrossRef]

Lia and Kjøk. 2001. Islamist Insurgencies, Diasporic Support Networks, and Their Host States-The Case of the Algerian GIA in Europe 1993-2000. Kjeller: FFI. Available online: https:/ / publications.ffi.no/nb/item/asset/dspace:3749/01-03789.pdf (accessed on 12 February 2022).

Los Angeles Times. 2005. 3 Iraqis Charged in Alleged Plot to Kill Allawi, November 17. Available online: https://www.latimes.com/ archives/la-xpm-2005-nov-17-fg-germany17-story.html (accessed on 18 November 2005).

Maisel, Sebastian. 2018. The Kurds: An Encyclopedia of Life, Culture, and Society. Santa Barbara: ABC Clio.

Majallat Ansar al-Sunnah. 2004. Al-Irhab al-mahmud. Jumada al-Ula 1425, June-July. Available online: https:/ /www-int.hf.uio.no/ ikos/english/research/jihadi-document-repository/journals/arabic/iraq/ansar-al-sunna/2004/ansar-al-sunna-no.10-july-20 04.pdf (accessed on 15 December 2021).

Majallat Ansar al-Sunnah. 2006a. SPECIAL File: Victory of the Prophets' Seal. No. 14 (Safar 1327/March 2006). pp. 7-17. Available online: https:/ / www-int.hf.uio.no/ikos/english/research/jihadi-document-repository/journals/arabic/iraq/ansar-al-sunna/ 2006/ansar-al-sunna-no.14-apr-2006.pdf (accessed on 15 December 2021). (In Arabic)

Majallat Ansar al-Sunnah. 2006b. The Goals of Jihad and Its Objectives. No. 14. (Safar 1327/March 2006). p. 23. Available online: https://www-int.hf.uio.no/ikos/english/research/jihadi-document-repository/journals/arabic/iraq/ansar-al-sunna/ 2006/ansar-al-sunna-no.14-apr-2006.pdf (accessed on 15 December 2021). (In Arabic)

Malazada, Ibrahim S., and Bahman T. Nariman. 2019. Jihadi Ideology in Eastern Kurdistan/Iran and Its Influences on The Southern Kurdistan Region/Iraq. Paper presented at ICABEP2019: International Conference on Accounting, Business, Economics and Politics, Erbil, Iraq. Available online: https://business.tiu.edu.iq/icabep/syrian-kurds-a-new-turkeys-nuisance-challengesconcerns / (accessed on 7 February 2022).

McKiernan, Kevin. 2002. Al Qaeda Base in Kurdistan? ABCNews, December 31. Available online: https://abcnews.go.com/ International/story?id=79713 (accessed on 7 February 2022).

Mishal, Shaul, and Maoz Rosenthal. 2005. Al Qaeda as a Dune Organization: Toward a Typology of Islamic Terrorist Organizations. Studies in Conflict E Terrorism 28: 275-93. [CrossRef]

Mu'assasat al-Ansar al-I'lamiyya. 2020. Videos, September 12-December 25. Available online: https://alaansaar.com/videos/ (accessed on 20 April 2020). (In Arabic)

Muntadiyat al-Hikma. 2005. The Names of the Arab Martyrs in Iraq... Is Constantly Being Renewed... The Ansar and the Muhajirun, April 26. Available online: www.hkmah.net/showthread.php?t=4555 (accessed on 26 April 2005). (In Arabic)

Muntadiyat Usama al-Islamiyya. 2004. Communiqué from the Martyr Umar al-Mukhtar Battalion, August 21. Available online: www.almjlah.net/vb/showthread.php?t=137 (accessed on 19 January 2005). (In Arabic)

NBC News. 2003. Bin Laden Allegedly Planned Attack in Turkey, December 17. Available online: https://www.nbcnews.com/id/ wbna3735645 (accessed on 15 December 2021).

Nesser, Petter. 2015. Islamist Terrorism in Europe: A History. London: Hurst.

New York Times. 2002a. Kurdish Leader May Spare Man Who Tried to Kill Him. New York Times, December 31.

New York Times. 2002b. Repulsing Attack by Islamic Militants, Iraqi Kurds Tell of Atrocities. New York Times, December 6. 
New York Times. 2003a. Kurdish Leader Is Assassinated in Militant Raid. New York Times, February 10.

New York Times. 2003b. Kurds Hope U.S. Bombs Hit Militants, Not Home. New York Times, February 17.

O'Leary, Brendan. 2006. Postscript: Vistas of Exits from Baghdad. In The Future of Kurdistan in Iraq. Edited by Brendan O'Leary, John McGarry and Khālid Șālih. Philadelphia: University of Pennsylvania Press, pp. 282-307.

Oberlandesgericht München. 2006. Urteil [...] in dem Strafverfahren gegen Lokman Amin Hama Karim, Aktenzeichen: 6 St 001/05. Oberlandesgericht München, January 12.

Panorama. 2003. Dirty Alliance in the Name of Usama. Panorama, April 24. Retrieved via Foreign Broadcast Information Service. (In Italian)

Parliament of Australia. 2009. Review of the re-listing of Ansar al-Islam, AAA, IAA, IMU, JeM and LeJ as Terrorist Organisations. Appendix B: Statement of Reasons-Ansar al-Islam (Formerly Ansar al-Sunna). Available online: https: //www.aph.gov.au/parliamentary_business/committees/house_of_representatives_committees?url=pjcis/six\%20terrorist / report/appendix\%20b.pdf (accessed on 15 December 2021).

Prieto, Monica G. 2003. Militant group Ansar al-Sunnah Army interviewed-Spanish daily [Title Given by FBIS, Not Original Headline]. El Mundo, October 5, Retrieved via Foreign Broadcast Information Service (FBIS). Internet Version.

Qisas Shuhada' al-'Arab. 2003. Min Qisas al-Shuhada' al-'Arab: Abu Shahid al-Sharqi 69, April. Available online: https://web.archive. org/web/20030424182339/www.saaid.net/Doat/hamad/59.htm (accessed on 19 April 2005).

Reuters. 2004. Turkey Charges 9, Frees 7 in NATO Bomb Plot: Al-Qaida-Linked Group Eyed Attacks at Summit in Istanbul, May 3. Available online: https:/ / www.nbcnews.com/id/wbna4889343 (accessed on 5 June 2005).

Romano, David. 2007. An Outline of Kurdish Islamist Groups in Iraq. Occasional Paper. Jamestown Foundation. Available online: https:/ /jamestown.org/wp-content/uploads/2007/09/Romano-OP.pdf (accessed on 15 December 2021).

Rubin, Michael. 2004. Ansar al-Sunna: Iraq's New Terrorist Threat. Middle East Intelligence Bulletin, p. 6. Available online: https: / / web.archive.org/web/20040614201435/www.meib.org/articles/0405_iraq1.htm (accessed on 15 December 2021).

Rumsfeld, Donald. 2011. Known and Unknown: A Memoir. New York: Sentinel.

Schanzer, Jonathan. 2003. Ansar al-Islam: Iraq's al-Qaeda Connection. Policy Watch No. 699. Washington, DC: Washington Institute for Near East Policy, January 15.

Schanzer, Jonathan. 2004a. Ansar al-Islam: Back in Iraq. Middle East Quarterly 11: 41-50. Available online: www.meforum.org/article/ 579 (accessed on 1 December 2005).

Schanzer, Jonathan. 2004b. Al-Qaeda's Armies: Middle East Affiliate Groups E the Next Generation of Terror. Washington, DC: Washington Institute for Near East Policy.

Shabakat al-Akhbar al-'Alamiyya. 2006. NOW: The Full Transcript of Sheikh Zarqawi's Video', April 26. Available online: http: / / www.world-news-network.net/showthread.php?t=12069 (accessed on 6 May 2006). (In English).

Shareef, Mohammed. 2015. Kurdish Islamists in Iraq from the Muslim Brotherhood to the So-Called Islamic State: Continuity or Departure? Riyadh: King Faisal Center for Research and Islamic Studies. Available online: https:/ /www.kfcris.com/pdf/a591440c858d2cc8 e1dd3dd5fd14470057cc9a7e1d268.pdf (accessed on 15 December 2021).

Sorany, Hashim. 2012. Der Politische Islam und Islamistischer Radikalismus in Süd-Kurdistan Von 1980 bis 2003. Ph.D. dissertation, Rheinischen-Friedrich-Wilhelms-Universität, Bonn, Germany.

Spiegel Online. 2003. Islamists Planned Attack on Bundeswehr Hospital. Spiegel Online, December 30. Retrieved via Foreign Broadcast Information Service. (In German)

Stavanger Aftenblad. 2003. Krekar Avsatt som Ansar al-Islam-leder i Februar 2003 [Krekar Deposed as Ansar al-Islam's Leader in February 2003], January 11. Available online: https:/ / www.aftenbladet.no/utenriks/i/aKak2/krekar-avsatt-som-ansar-al-islamleder-i-februar-2003 (accessed on 8 February 2022).

Steinberg, Guido. 2008. The Threat of Jihadist Terrorism in Germany. Madrid: Real Instituto Elcano, November 6. Available online: http:/ / biblioteca.ribei.org/id/eprint/1480/1/ARI-142-2008-I.pdf (accessed on 15 December 2021).

Task \& Purpose. 2020. The Inside Story of the DEADLIEST attack on a U.S. Military Base during the Iraq War, December 2. Available online: https:/ / taskandpurpose.com/news/iraq-war-fob-marez-bombing/ (accessed on 8 February 2022).

Tenet, George. 2007. At the Center of the Storm: My Years at the CIA. New York: HarperCollins.

The Christian Science Monitor. 2005. Sweden's Rising Muslim Tide: Home to One of Europe's most Muslim Cities, the Country May Also Be Host to Increasing Radicalism, December 6. Available online: www.csmonitor.com/2005/1206/p07s02-woeu.html (accessed on 15 May 2006).

The Guardian. 2003. 'This Makes Us Love Saddam, not America': 34 Die as US Missiles Hit Wrong Target, March 24. Available online: www.guardian.co.uk/international/story/0,3604,920556,00.html (accessed on 1 May 2006).

The Guardian. 2004. Unnamed Turkish Police Officials cited in '16 Suspected Islamist Militants held', May 3. Available online: www.guardian.co.uk/turkey/story/0,12700,1208595,00.html (accessed on 15 June 2005).

The Scotsman. 2004. Sixteen Held as Police "Foil Plot Aimed at NATO Summit", May 4. Available online: http://news.scotsman.com/ topics.cfm?tid=825\&id=505822004 (accessed on 5 June 2005).

The Sydney Morning Herald. 2002. Al-Qaeda's Hideaway, December 26. Available online: https://www.smh.com.au/world/alqaedas-hideaway-20021226-gdg0po.html (accessed on 7 February 2022).

Tønnessen, Truls Hallberg. 2014. Al-Qaida in Iraq: The Rise, the Fall and the Comeback. Ph.D. dissertation, University of Oslo, Oslo, Norway. 
U.S. Department of State. 2015. Country Reoirt in Terrorism 2014, June. Available online: https:/ /2009-2017.state.gov/documents / organization/239631.pdf (accessed on 8 February 2022).

U.S. Department of the Treasury. 2006. Treasury Designations Target Terrorist Facilitators, December 7. Available online: https: / / web.archive.org/web/20061208041422/https://www.treasury.gov/press/releases/hp191.htm (accessed on 8 February 2022).

United Nations. 2006. The New Consolidated List Of individuals and Entities Belonging to or Associated with the Taliban and al-Qaida organisation as Established and Maintained by the 1267 Committee. Available online: https://web.archive.org/web/2006051316 3829/http:/ / www.un.org/Docs/sc/committees/1267/pdflist.pdf (accessed on 2 May 2006).

Västmanslands Tingsrätt. 2012. Förundersökning. Justitekanslern Vid Högsta Domstolen. [German Request for Legal Aid in Investigation of Terrorism Suspects, Including Mullah Krekar]. Västmanslands Tingsrätt, December 17.

Voice of America. 2009. Three Suspects in Iraqi Assassination Plot Stand Trial in Germany, October 31. Available online: https: //www.voanews.com/a/a-13-2006-06-20-voa47/320242.html (accessed on 2 February 2022).

Vindheim, Jan Boyer. 2005. Ansar al-Islam og Kurdisk Islamisme. Babylon: Nordisk tidsskrift for Midtøstenstudier 3: 138-47. Available online: https://journals.uio.no/babylon/article/view/4159 (accessed on 15 December 2021).

Weiss, Caleb. 2019. Ansar al Islam Claims First Attack in Iraq Since 2014. The Long War Journal-Threat Matrix, October 31. Available online: https: / / www.longwarjournal.org/archives/2019/10/ansar-al-islam-claims-first-attack-in-iraq-since-2014.php (accessed on 8 February 2022).

Wollstad. 2006. Financing of Terrorism: A Court Case in Sweden. Powerpoint-Presentation by Solveig Wollstad, National Member of Sweden at International Criminal Law Network's Annual Conference. Available online: https://web.archive.org/web/20070623 092746/http:/ / www.icln.net/htm/Annual\%20conference\%202006/Presentation_Wollstad.pdf (accessed on 15 December 2021). 